\title{
Effects of riparian buffers on nitrate concentrations in watershed discharges: new models and management implications
}

\author{
Donald E. Weller, ${ }^{1}$ Matthew E. Baker, ${ }^{2}$ And Thomas E. Jordan \\ Smithsonian Environmental Research Center, P.O. Box 28, 647 Contees Wharf Road, Edgewater, Maryland 21037-0028 USA
}

\begin{abstract}
Watershed analyses of nutrient removal in riparian buffers have been limited by the geographic methods used to map buffers and by the statistical models used to test and quantify buffer effects on stream nutrient levels. We combined geographic methods that account for buffer prevalence along flow paths connecting croplands to streams with improved statistical models to test for buffer effects on stream nitrate concentrations from 321 tributary watersheds to the Chesapeake Bay, USA. We developed statistical models that predict stream nitrate concentration from watershed land cover and physiographic province. We used information theoretic methods $\left(\mathrm{AIC}_{\mathrm{c}}\right)$ to compare models with and without buffer terms, and we demonstrate that models accounting for riparian buffers better explain stream nitrate concentrations than models using only land cover proportions. We analyzed the buffer model parameters to quantify differences within and among physiographic provinces in the potentials for nitrate loss from croplands and nitrate removal in buffers. On average, buffers in Coastal Plain study watersheds had a higher relative nitrate removal potential $(95 \%$ of the inputs from cropland) than Piedmont buffers (35\% of inputs). Buffers in Appalachian Mountain study watersheds were intermediate (retaining $39 \%$ of cropland inputs), but that percentage was uncertain. The absolute potential to reduce nitrate concentration was highest in the Piedmont study watersheds because of higher nitrate inputs from cropland. Model predictions for the study watersheds provided estimates of nitrate removals achieved with the existing cropland and buffer distributions. Compared to expected nitrate concentrations if buffers were removed, current buffers reduced average nitrate concentrations by $0.73 \mathrm{mg} \mathrm{N} / \mathrm{L}$ ( $50 \%$ of their inputs from cropland) in the Coastal Plain study watersheds, $0.40 \mathrm{mg} \mathrm{N} / \mathrm{L}(11 \%)$ in the Piedmont, and $0.08 \mathrm{mg} \mathrm{N} / \mathrm{L}(5 \%)$ in the Appalachian Mountains. Restoration to close all buffer gaps downhill from croplands would further reduce nitrate concentrations by $0.66 \mathrm{mg}$ $\mathrm{N} / \mathrm{L}, 0.83 \mathrm{mg} \mathrm{N} / \mathrm{L}$, and $0.51 \mathrm{mg} \mathrm{N} / \mathrm{L}$, respectively, in the Coastal Plain, Piedmont, and Appalachian Mountain study watersheds. Aggregate nitrate removal by riparian buffers was less than suggested by many studies of field-to-stream transects, but buffer nitrate removal is significant, and restoration could achieve substantial additional removal.
\end{abstract}

Key words: Chesapeake Bay watershed; collinearity; flow path analysis; land cover; nitrate; nitrogen; nutrient discharges; riparian buffer; watershed analysis; watershed management.

\section{INTRODUCTION}

Nonpoint-source pollution from anthropogenic nitrogen inputs is a well-documented challenge for resource managers, regulatory agencies, and policy makers (Jordan and Weller 1996, Carpenter et al. 1998); especially in $\mathrm{N}$-limited coastal waters where the resulting eutrophication can have dramatic ecological consequences (Turner and Rabalais 1991, Boesch et al. 2001, Rabalais et al. 2001). In the Chesapeake Bay drainage, row crop agriculture is the dominant nutrient source (Jordan et al. 1997a, b, 2003, Preston and Brakebill 1999, Linker et al. 2000, Liu et al. 2000), and

Manuscript received 20 April 2010; revised 29 September 2010; accepted 8 October 2010. Corresponding Editor: M. J. Vander Zanden.

${ }^{1}$ E-mail: wellerd@si.edu

2 Present address: Department of Geography and Environmental Systems, University of Maryland-Baltimore County, Baltimore, Maryland 21250 USA. nitrogen discharges to the Bay have caused eutrophication and related ecological damage (Boesch et al. 2001, Hagy et al. 2004, Kemp et al. 2005). Restoration of forested buffers along streams has been emphasized as a nutrient control mechanism (Lowrance et al. 1997, Mayer et al. 2007, Dosskey et al. 2010), and 59\% of watershed restoration projects in the Chesapeake basin have focused on riparian reforestation (Hassett et al. 2005). Ongoing management plans and recent Federal Government initiatives propose additional riparian restoration to reduce nutrient loads to Chesapeake Bay (U.S. Environmental Protection Agency 2006, 2009, Federal Leadership Committee for the Chesapeake Bay 2010).

Most of our knowledge of nitrogen removal by riparian buffers comes from studies that track nitrogen concentrations across individual riparian areas (e.g., Lowrance et al. 1997, Mayer et al. 2007). Many studies report substantial nitrogen removal along field-to- 


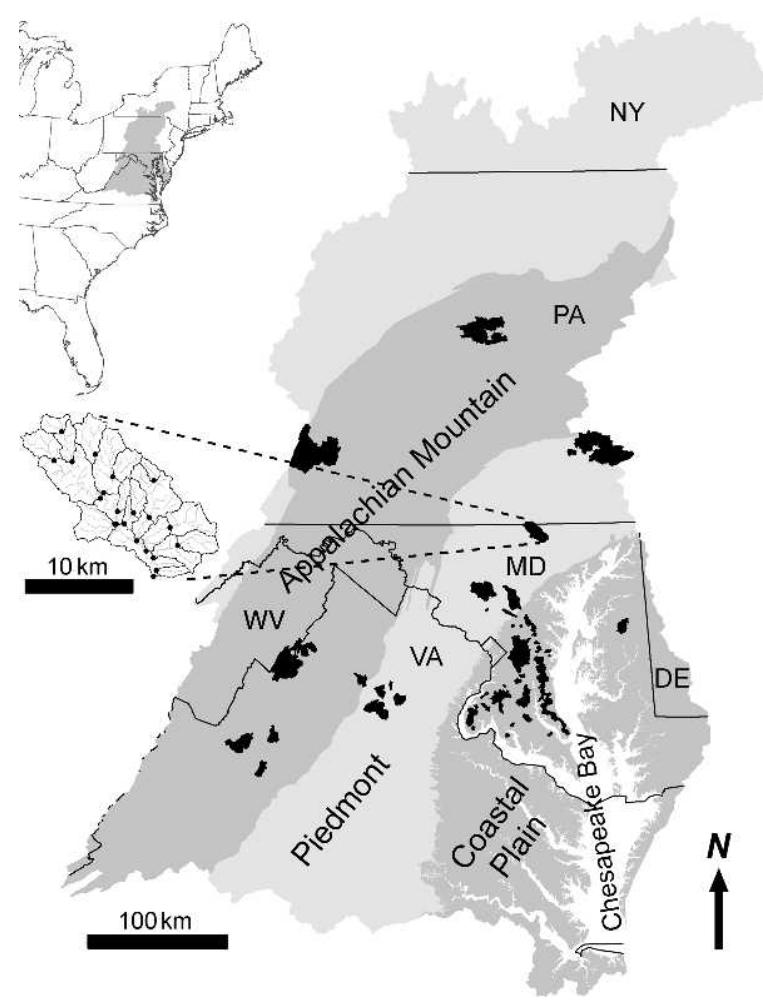

FIG. 1. Study watersheds (black shading) in three major physiographic provinces of the Chesapeake Bay basin. The upper inset shows the location of the Chesapeake basin (shaded) within the eastern United States. The lower inset expands one watershed cluster to show watershed boundaries, streams, and sampling points.

stream transects (Lowrance al. 1984, Peterjohn and Correll 1984, Jacobs and Gilliam 1985, Cooper 1990, Jordan et al. 1993), but other studies report no effect or inefficient nitrogen removal (Denver 1991, Osborne and Kovacic 1993, Altman and Parizek 1995, Hill 1996, Correll et al. 1997, Sabater et al. 2003, Hefting et al. 2004, Vidon and Hill 2004, Mayer et al. 2007, Speiran 2010). Because some buffers do not remove nitrogen, the cumulative watershed impact of riparian zones on stream nutrient levels remains poorly understood (Weller et al. 1998, Vidon et al. 2008). Empirical estimates of buffer nutrient removal across watersheds are needed to test if the high nutrient removals reported for some transects are achieved more broadly, to provide realistic expectations for nutrient reductions from buffer restoration, and to integrate buffer restoration into effective (e.g., Gregory et al. 2007, Diebel et al. 2009, Maxted et al. 2009) and adaptive management programs (National Research Council 2004).

Watershed analyses of buffer effects have been limited by the geographic analyses used to map buffers and by the statistical models used to test for buffer effects on stream nutrient levels. Few studies have reported statistically significant buffer effects on stream nutrient levels and none has quantified the aggregate nutrient removal by all buffers in a watershed (Weller et al. 1998). Riparian buffer prevalence in watersheds is typically measured by summarizing land cover proportions within a fixed distance of streams. Such measures do not consider the arrangement of buffers along flow pathways between source areas and streams, they ignore buffers outside of the fixed zone, and they can include areas that are irrelevant to nutrient removal because they lack upslope nutrient sources (Baker et al. 2006a). Previous analyses have tested for buffer effects by including buffer measures in stepwise multiple linear regression models that predict nutrient levels from land cover and other watershed attributes (e.g., Johnson et al. 1997, Jones et al. 2001). The stepwise regression approach necessarily leads to a surfeit of candidate models, does not clearly test a hypothesis about the relationship between buffers and watershed discharges, and does not quantify buffer nutrient removal. Despite these problems, stepwise multiple regression models and fixed-distance measures of riparian buffers are still used to assess land use effects on Chesapeake Bay water quality (e.g., Jones et al. 2001, Day and Crew 2005, Claggett et al. 2010).

Here we analyze nutrient removal in the riparian buffers of rural watersheds where we have studied the effects of land use on water quality (Liu et al. 2000). We apply our recently developed geospatial methods to quantify riparian buffer prevalence along flow paths draining croplands (Baker et al. 2006a, 2007), and then we incorporate the buffer measures into a new statistical modeling framework that can test for buffer effects and quantify buffer nitrate removal. We rely on previous research to build a parsimonious model set tailored to test for the effects of buffers on watershed nitrate losses (see Burnham and Anderson 2002), and then we use information theory to compare models with and without buffer effects. Our comparison demonstrates that models including descriptions of buffer prevalence better explain stream nitrate concentrations than models using only land cover proportions. We apply the buffer models to estimate cropland nitrate discharges, buffer nitrate removals, and differences in these quantities among study watersheds in three physiographic provinces. We report findings from these analyses and discuss their implications for riparian buffer and watershed management.

\section{Methods \\ Study watersheds}

We studied 321 rural watersheds selected for their differing proportions and arrangements of land cover. The watersheds are located in 12 clusters (Fig. 1) distributed across three major physiographic provinces (Langland et al. 1995) within the Chesapeake Bay Drainage: Coastal Plain (111 watersheds), Piedmont (113), and Appalachian Mountain (97). Liu et al. (2000) provided detailed descriptions of land cover, physiographic province, and water chemistry, and Baker et al. (2006a, 2007) analyzed 
patterns of riparian buffer prevalence among and within physiographic provinces. Water chemistry samples were collected from each watershed outlet quarterly for four seasons or longer in the mid 1990s, filtered, refrigerated, and analyzed by a Dionex (Sunnyvale, California, USA) Ion Chromatograph for nitrate-N (Liu et al. 2000). In this analysis, we use the average of all the quarterly nitrate concentration measurements for each watershed. Stream discharge data were not available for most of the study watersheds, so we develop models to predict annual average nitrate concentration (in $\mathrm{mg} \mathrm{N} / \mathrm{L}$ ) in the stream leaving a watershed rather than to predict annual nitrate yield $\left(\mathrm{mg} \mathrm{N} \cdot \mathrm{ha}^{-1} \cdot \mathrm{yr}^{-1}\right.$ ). Models that predict nutrient concentration tend to emphasize factors that supply or remove nutrients, while models that predict nutrient yield are often dominated by the factors that control water flow (Weller et al. 2003).

\section{Geographic data sources}

We used the ArcGIS 9.3 (ESRI, Inc., Redlands, California, USA) geographic information system (GIS) to analyze publicly available maps of topography $(30-\mathrm{m}$ digital elevation models, National Elevation Dataset [NED; Gesch et al. 2002]), streams (the 1:24 000 medium resolution National Hydrography Dataset [NHD; Simley and Carswell 2009]), and land cover (1992 National Land Cover Dataset [NLCD; Vogelmann et al. 1998a, 1998b, U.S. Environmental Protection Agency 2000]). Watershed outlets were located in the GIS by digitizing stream sampling points marked on 7.5-minute USGS quadrangle maps. Watershed boundaries were manually digitized from contour lines and streams on the quadrangle maps and county ditch maps (Liu et al. 2000) and later updated using automated watershed delineation based on digital elevation and stream maps (Baker et al. 2006b). For each watershed, we estimated the proportions of cropland, grassland, and developed land, and the sum of the proportions of forest and wetlands.

\section{Buffer metric calculation}

We characterized riparian buffers using measures of buffer presence along flow paths linking croplands to streams (Weller et al. 1998, Baker et al. 2006a, 2007). We used the digital elevation model to identify surface transport pathways following the steepest descent from cropland pixels to a stream (O'Callaghan and Mark 1984) and then measured the width of riparian buffer along each path, where riparian buffer was defined as forest or wetland land cover that was contiguous with the stream (i.e., connected to the stream channel by an unbroken chain of forest or wetland pixels; Baker et al. $2006 a$, 2007). For each watershed, we estimated mean buffer width $\left(\mathrm{MBW}_{\mathrm{c}}\right)$ by averaging buffer widths across all cropland-to-stream flow paths (the subscript $\mathrm{c}$ emphasizes that $\mathrm{MBW}_{\mathrm{c}}$ describes only flow paths originating in croplands). We also estimated the frequency of gaps $\left(\mathrm{FGAP}_{\mathrm{c}}\right)$ as the percentage of cropland pixels whose flow paths do not pass through a buffer (Weller et al. 1998, Baker et al. 2006a, 2007). We calculated the mean inverse of buffer width $\left(\mathrm{MIBW}_{\mathrm{c}}\right)$ as the watershed average across all cropland to stream flow paths of $1 /(w+1)$, where $w$ is the width of riparian buffer traversed by a flow path (Baker et al. 2006a). Inverse buffer width represents the empirical result that nitrate concentration declines with transport distance through buffers (e.g., Lowrance et al. 1997), so MIBW $_{\mathrm{c}}$ estimates buffer potential aggregated across a watershed (Baker et al. 2006a, 2007). We found that $\mathrm{MIBW}_{\mathrm{c}}$ was redundant with $\mathrm{FGAP}_{\mathrm{c}}$ (see Results) because the $30-\mathrm{m}$ resolution of the land cover data precluded quantifying narrow buffer widths (see Discussion), so we used FGAP $_{\mathrm{c}}$ as the measure of buffer prevalence in our statistical models.

\section{Statistical models}

Land proportion model.-Previous analyses had already identified important land cover variables for predicting nitrate concentrations in our study watersheds (Jordan et al. 1997a, b, c, Liu et al. 2000). Here, we included the proportions of cropland and developed land because cropland is the strongest predictor of stream nitrate concentrations, and developed land has a significant but weaker effect (Jordan et al. 1997b, 2003, Liu et al. 2000, Weller et al. 2003, King et al. 2005). We also included grassland proportion because grasslands can contain nitrate sources (fertilized pastures, hayfields, and lawns) and because land cover data sets often confuse croplands with grasslands (Liu et al. 2000, Weller et al. 2003).

We also expected that cropland would have stronger effects on stream nitrate concentrations in the Piedmont than in other physiographic provinces (Jordan et. al. 1997a, b, c, 2003, Bachman et al. 1998, Preston and Brakebill 1999, Liu et al. 2000). We represented this in the model by including physiographic province as a categorical independent variable and by including the statistical interaction of cropland proportion with physiographic province. This approach estimates for each province a distinct intercept and coefficient for nitrate per unit watershed cropland proportion, thus accommodating differences among provinces in a single model. We also tested for differences among provinces in the effect of grassland, but we did not attempt to resolve province-specific effects of developed land because most of our study watersheds did not include much developed land (Liu et al. 2000). The linear model equation for the initial land proportion model was then

$$
\begin{aligned}
N= & \underbrace{\beta_{0}+\beta_{0 \mathrm{p}} P_{\mathrm{p}}+\beta_{0 \mathrm{a}} P_{\mathrm{a}}}_{\text {background }}+\underbrace{\left(\beta_{\mathrm{c}}+\beta_{\mathrm{cp}} P_{\mathrm{p}}+\beta_{\mathrm{ca}} P_{\mathrm{a}}\right) C}_{\text {cropland }} \\
& +\underbrace{\left(\beta_{\mathrm{g}}+\beta_{\mathrm{gp}} P_{\mathrm{p}}+\beta_{\mathrm{ga}} P_{\mathrm{a}}\right) G}_{\text {grassland }}+\underbrace{\beta_{\mathrm{d}} D}_{\text {developed land }}+\varepsilon
\end{aligned}
$$


where $N$ is nitrate concentration; $C, G$, and $D$ are the proportions of cropland, grassland, and developed land; $\beta$ values are fitted model coefficients; $\varepsilon$ is error; and $P_{\mathrm{p}}$ and $P_{\mathrm{a}}$ are dummy variables representing the categorical variable physiographic province. $P_{\mathrm{p}}=1$ for the Piedmont province and zero otherwise, whereas $P_{\mathrm{a}}=1$ for the Appalachian Mountain province and zero otherwise. For the Coastal Plain, both $P_{\mathrm{p}}$ and $P_{\mathrm{a}}$ are zero. The first subscript on a coefficient $\beta$ represents the land cover to which that coefficient applies (c, g, or $\mathrm{d}$ for cropland, grassland, or developed land). If present, the second subscript represents the dummy variable for physiographic province to which the coefficient applies ( $\mathrm{p}$ or a for $P_{\mathrm{p}}$ or $P_{\mathrm{a}}$ ). We used the $1 \mathrm{~m}$ function of the $\mathrm{R}$ statistical package (R Development Core Team 2008) and PROC GLM in the SAS statistical package (SAS Institute 2004) to fit all models. Results from the two statistical packages were equivalent.

We examined the analysis of variance table for the full model (Eq. 1), and eliminated terms that were not statistically significant after accounting for other predictors ( $F$ test based on the Type III sum of squares). The interaction of grassland with physiographic province was not statistically significant $\left(F_{2,311}=0.06, P=\right.$ $0.94)$, so it was removed to produce a reduced land cover proportion (LP) model:

$$
\begin{aligned}
N= & \underbrace{\beta_{0}+\beta_{0 \mathrm{p}} P_{\mathrm{p}}+\beta_{0 \mathrm{a}} P_{\mathrm{a}}}_{\text {background }}+\underbrace{\left(\beta_{\mathrm{c}}+\beta_{\mathrm{cp}} P_{\mathrm{p}}+\beta_{\mathrm{ca}} P_{\mathrm{a}}\right) C}_{\text {all cropland }} \\
& +\underbrace{\beta_{\mathrm{g}} G}_{\text {grassland }}+\underbrace{\beta_{\mathrm{d}} D}_{\text {developed land }}+\varepsilon .
\end{aligned}
$$

The effects of developed land and grassland were also not significant, but these terms were initially retained to compare the magnitudes of their coefficients $\left(\beta_{\mathrm{d}}\right.$ and $\left.\beta_{\mathrm{g}}\right)$ to the magnitude of the effect of cropland per unit watershed proportion $\left(\beta_{\mathrm{c}}, \beta_{\mathrm{cp}}\right.$, and $\left.\beta_{\mathrm{ca}}\right)$. A more parsimonious model (LPp) dropping these nonsignificant terms was also considered (see Results).

Buffer model.-We added buffer effects to the LP model (Eq. 2) by including unbuffered cropland as an independent variable. In the simple case when cropland is the only nitrate source and there are no differences among provinces to consider, stream nitrate concentration can be predicted with the linear model:

$$
N=\beta_{0}+\beta_{\mathrm{c}} C+\varepsilon
$$

where symbols are as defined for Eq. 1. However, the cropland proportion for any watershed can be divided into watershed proportions of buffered cropland $\left(C_{\mathrm{b}}\right)$ and unbuffered cropland $\left(C_{\mathrm{u}}\right)$ :

$$
C=C_{\mathrm{b}}+C_{\mathrm{u}}
$$

where

$$
C_{\mathrm{u}}=C \times \mathrm{FGAP}_{\mathrm{c}}
$$

is the product of cropland proportion and the fraction of flow paths starting in cropland that is not buffered. The two variables $C_{\mathrm{b}}$ and $C_{\mathrm{u}}$ cannot simply replace $C$ in a statistical model because they are an exact linear combination (Eq. 4) so the model could not be solved (Freund and Minton 1979). However, $C_{\mathrm{u}}$ can be added to the nitrate model (Eq. 3) to yield a model that distinguishes the effects of buffered and unbuffered cropland:

$$
N=\beta_{0}+\beta_{\mathrm{c}} C+\beta_{\mathrm{u}} C_{\mathrm{u}}+\varepsilon
$$

where the term $\beta_{\mathrm{u}} C_{\mathrm{u}}$ represents the additional nitrate released by unbuffered cropland beyond the amount $\left(\beta_{\mathrm{c}} C\right)$ released by all cropland. The variables $C$ and $C_{\mathrm{u}}$ are obviously correlated because $C_{\mathrm{u}}$ is calculated from $C$ (Eq. 5), so we tested for possible deleterious effects of collinearity (Neter et al. 1990) on model fitting, on parameter interpretation, and on predictions of nitrate levels for watersheds not used in model development (Appendix). Incorporating the logic of Eq. 6 into the land proportion model (Eq. 2) along with terms to represent differences among provinces gives the buffer effects (BF) model:

$$
\begin{aligned}
N & =\underbrace{\beta_{0}+\beta_{0 \mathrm{p}} P_{\mathrm{p}}+\beta_{0 \mathrm{a}} P_{\mathrm{a}}}_{\text {background }}+\underbrace{\left(\beta_{\mathrm{c}}+\beta_{\mathrm{cp}} P_{\mathrm{p}}+\beta_{\mathrm{ca}} P_{\mathrm{a}}\right) C}_{\text {cropland }} \\
& +\underbrace{\left(\beta_{\mathrm{u}}+\beta_{\text {up }} P_{\mathrm{p}}+\beta_{\text {ua }} P_{\mathrm{a}}\right) C_{\mathrm{u}}}_{\text {unbuffered cropland }}+\underbrace{\beta_{\mathrm{g}} G}_{\text {grassland }} \\
& +\underbrace{\beta_{\mathrm{d}} D}_{\text {developed land }}+\varepsilon
\end{aligned}
$$

where the subscript $u$ designates coefficients $\beta$ for unbuffered cropland, and other notation is as described for Eq. 1. After fitting the model (Eq. 7), we again examined $F$ tests for Type III sums of squares to eliminate nonsignificant terms and yield two models that were more parsimonious ( $\mathrm{BFp}$ and $\mathrm{BFp}+$ ).

Model evaluation.-We used coefficients of determination $\left(R^{2}\right)$ and the corrected Akaike information criterion $\left(\mathrm{AIC}_{\mathrm{c}}\right)$ to compare models with and without buffer effects. $\mathrm{AIC}_{\mathrm{c}}$ is a model-selection tool based on information theory (Burnham and Anderson 2002). $\mathrm{AIC}_{\mathrm{c}}$ imposes a penalty for adding model parameters, so that a more complex model is "better" than a simpler one only if the extra complexity yields an increase in explanatory power that more than offsets the penalty. Within a model set, the model with the minimum $\mathrm{AIC}_{\mathrm{c}}$ is the best, and the relative quality of any two models can be judged by difference between their $\operatorname{AIC}_{\mathrm{c}}$ values $(\Delta)$. $\mathrm{AIC}_{\mathrm{c}}$ differences of less than two indicate models of similar quality, differences greater than four favor the model with the lower $\mathrm{AIC}_{\mathrm{c}}$, and differences greater than 10 constitute strong evidence for the model with smaller $\mathrm{AIC}_{\mathrm{c}}$ (Burnham and Anderson 2002). $\mathrm{AIC}_{\mathrm{c}}$ values can also be used to calculate an Akaike weight for every model in a set. The Akaike weight is the probability that a model is the best candidate within the set of models, 
and the ratio of two Akaike weights is an estimate of the strength-of-evidence (relative probabilities) of the two models.

Model averaging.- $-\mathrm{AIC}_{\mathrm{c}}$ can identify the best model in a set, but it is not necessarily desirable to discard lower-ranked models. Inferences should be based on more than a single model, unless the data clearly support only one model (Burnham and Anderson 2002). Model averaging integrates a set of models and accounts for the additional uncertainty arising from differences among models (model selection uncertainty). The model average (MA) model is simply a weighted average of predictions or parameters where the weights are the model probabilities (Akaike weights). Models that are poorly supported by the data receive little weight, while models that are more likely contribute more strongly to the MA model. The variance of a MA model estimate is a weighted average of the variances from the separate models plus a term that estimates variance from model selection uncertainty (Burnham and Anderson 2002: Eq. 6.12). We applied the MA model parameters and predictions to draw inferences about the nitrate sources, nitrate removal potentials, and nitrate removal in the study watersheds.

\section{Nitrate source and buffer nitrate removal potentials}

MA model coefficients describe the general effects of cropland and riparian buffers on stream nitrate concentrations within the study watersheds in each physiographic province. Any coefficient can be interpreted as the expected contribution to stream nitrate concentration if a study watershed consisted solely of that land cover type, and all coefficients have the units of $\mathrm{mg} \mathrm{N} / \mathrm{L}$ per unit watershed proportion. In the simple case when all nitrate comes from cropland and there are no province differences (Eq. 6), the term $\beta_{\mathrm{u}} C_{\mathrm{u}}$ represents additional nitrate released by unbuffered cropland beyond the amount $\left(\beta_{\mathrm{c}} C\right)$ released by all cropland (Fig. 2). If all buffers were removed, then the currently buffered cropland $\left(C_{\mathrm{b}}\right)$ would also release additional nitrate at the rate given by coefficient $\beta_{\mathrm{u}}$. Therefore, the quantity $\beta_{\mathrm{u}} C_{\mathrm{b}}$ represents a component of nitrate not released with current buffers in place, that is, $\beta_{\mathrm{u}} C_{\mathrm{b}}$ is current nitrate removal in buffers. Thus, the parameter $\beta_{u}$ represents the absolute nitrate removal potential.

MA model coefficients also describe the edge-of-field nitrate loss from cropland, which is the input to riparian buffers. Substituting Eq. 4 into Eq. 6 and rearranging gives

$$
N=\beta_{0}+\beta_{\mathrm{c}} C_{\mathrm{b}}+\left(\beta_{\mathrm{c}}+\beta_{\mathrm{u}}\right) C_{\mathrm{u}}+\varepsilon
$$

where the term $\left(\beta_{\mathrm{c}}+\beta_{\mathrm{u}}\right) C_{\mathrm{u}}$ represents the direct input from unbuffered croplands to streams and $\beta_{\mathrm{c}} C_{\mathrm{b}}$ is the leakage to streams from buffered cropland. Adding the buffer nitrate removal $\beta_{\mathrm{u}} C_{\mathrm{b}}$ (see above) to buffer leakage $\beta_{\mathrm{c}} C_{\mathrm{b}}$ gives the edge-of-field input from cropland to buffers $\left(\beta_{\mathrm{c}}+\beta_{\mathrm{u}}\right) C_{\mathrm{b}}$. The rate of input from cropland to buffers $\left(\beta_{\mathrm{c}}+\beta_{\mathrm{u}}\right)$, is thus the same as the rate of direct output from unbuffered cropland to streams. The ratio of absolute nitrate removal

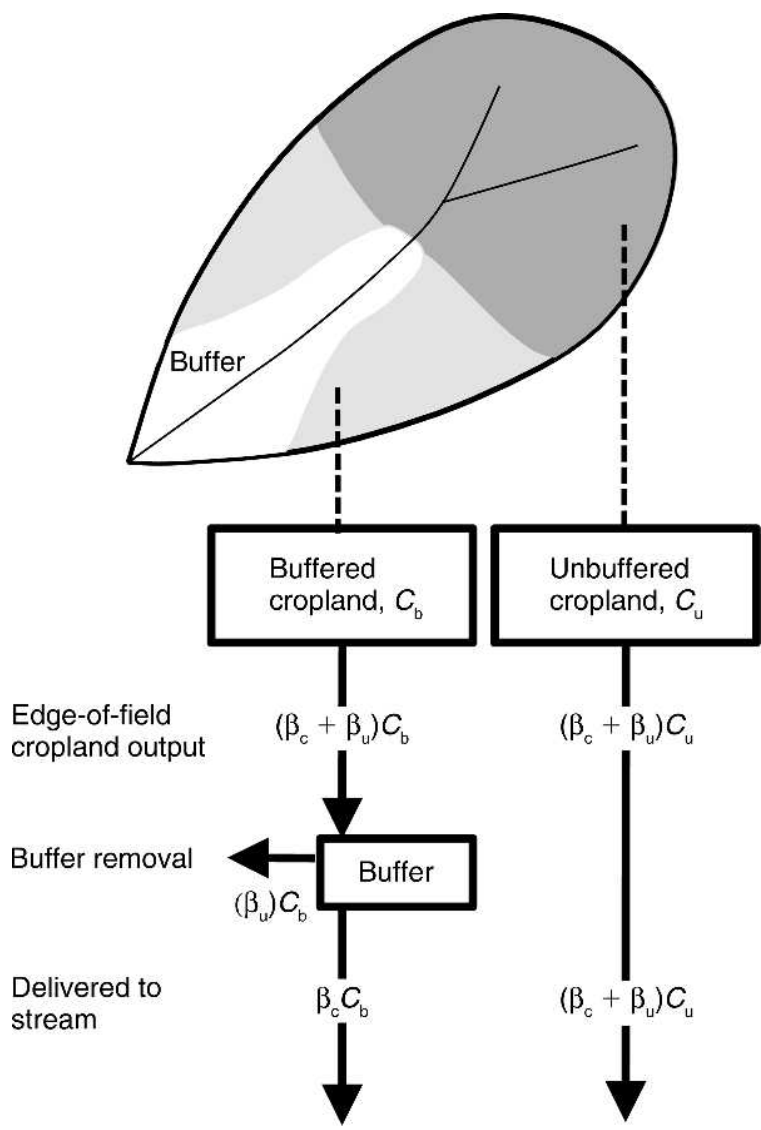

FIG. 2. Conceptual diagram illustrating parameter interpretation for a simple buffer model in which all nitrate comes from croplands (Eq. 6). The upper map shows streams (black lines), riparian buffer (white), buffered cropland (light gray), and unbuffered cropland (dark gray). For a buffer model that accommodates differences among provinces (Eq. 7), the parameter sum representing buffer removal is given by Eq. 9 , Eq. 10 represents delivery to the stream through buffers, and Eq. 11 represents both edge-of-field cropland output and delivery to the stream from unbuffered cropland.

$\left(\beta_{\mathrm{u}} C_{\mathrm{b}}\right)$ divided by nitrate input $\left(\beta_{\mathrm{c}}+\beta_{\mathrm{u}}\right) C_{\mathrm{b}}$ reduces to $\beta_{\mathrm{u}} /\left(\beta_{\mathrm{c}}+\beta_{\mathrm{u}}\right)$, a dimensionless number representing relative nitrate removal potential.

We applied the above logic to estimate provincespecific potentials from the parameters of the MA model by including the interaction terms that account for differences among provinces (Eq. 7):

Absolute nitrate removal potential:

$$
\left(\beta_{\mathrm{u}}+\beta_{\mathrm{up}} P_{\mathrm{p}}+\beta_{\mathrm{ua}} P_{\mathrm{a}}\right)
$$

Nitrate leakage from buffers:

$$
\left(\beta_{\mathrm{c}}+\beta_{\mathrm{cp}} P_{\mathrm{p}}+\beta_{\mathrm{ca}} P_{\mathrm{a}}\right)
$$

Input from cropland to buffers (also output from unbuffered cropland to streams):

$$
\left(\beta_{\mathrm{c}}+\beta_{\mathrm{cp}} P_{\mathrm{p}}+\beta_{\mathrm{ca}} P_{\mathrm{a}}+\beta_{\mathrm{u}}+\beta_{\mathrm{up}} P_{\mathrm{p}}+\beta_{\mathrm{ua}} P_{\mathrm{a}}\right)
$$


TABLE 1. Summary statistics for land cover fraction, buffer metrics, and average stream nitrate concentration for study watersheds in the Coastal Plain (CP, $n=111)$, Piedmont (PD, $n=113$ ), and Appalachian Mountain (AM, $n=97$ ) physiographic provinces.

\begin{tabular}{|c|c|c|c|c|}
\hline \multirow{2}{*}{$\begin{array}{c}\text { Variable } \\
\text { and province }\end{array}$} & \multirow[b]{2}{*}{ Mean } & \multirow[b]{2}{*}{ Median } & \multicolumn{2}{|c|}{ Percentile } \\
\hline & & & 5 th & 95th \\
\hline \multicolumn{5}{|c|}{ Cropland, $C$ (fraction) } \\
\hline $\mathrm{CP}$ & 0.137 & 0.083 & 0.006 & 0.408 \\
\hline PD & 0.107 & 0.105 & 0.005 & 0.234 \\
\hline $\mathrm{AM}$ & 0.070 & 0.041 & 0.001 & 0.266 \\
\hline \multicolumn{5}{|c|}{ Developed land, $D$ (fraction) } \\
\hline $\mathrm{CP}$ & 0.134 & 0.077 & 0.002 & 0.463 \\
\hline PD & 0.052 & 0.018 & 0.000 & 0.223 \\
\hline $\mathrm{AM}$ & 0.011 & 0.002 & 0.000 & 0.036 \\
\hline \multicolumn{5}{|c|}{ Grassland, $G$ (fraction) } \\
\hline $\mathrm{CP}$ & 0.210 & 0.194 & 0.052 & 0.445 \\
\hline PD & 0.463 & 0.478 & 0.133 & 0.698 \\
\hline $\mathrm{AM}$ & 0.411 & 0.410 & 0.016 & 0.766 \\
\hline \multicolumn{5}{|c|}{ Unbuffered cropland, $C_{\mathrm{u}}$ (fraction) } \\
\hline $\mathrm{CP}$ & 0.065 & 0.016 & 0.000 & 0.299 \\
\hline PD & 0.073 & 0.059 & 0.001 & 0.175 \\
\hline $\mathrm{AM}$ & 0.061 & 0.031 & 0.000 & 0.220 \\
\hline \multicolumn{5}{|c|}{ Mean buffer width, MBW $_{\mathrm{c}}(\mathrm{m})$} \\
\hline $\mathrm{CP}$ & 141 & 109 & 8 & 400 \\
\hline PD & 49 & 34 & 1 & 141 \\
\hline $\mathrm{AM}$ & 58 & 12 & 0 & 220 \\
\hline \multicolumn{5}{|c|}{ Buffer gap, FGAP $_{c}$ (fraction) } \\
\hline $\mathrm{CP}$ & 0.309 & 0.250 & 0.006 & 0.785 \\
\hline PD & 0.592 & 0.590 & 0.115 & 0.957 \\
\hline $\mathrm{AM}$ & 0.714 & 0.812 & 0.000 & 0.979 \\
\hline \multicolumn{5}{|c|}{ Mean inverse buffer width, MIBW $_{\mathrm{c}}(1 / \mathrm{m})$} \\
\hline $\mathrm{CP}$ & 0.326 & 0.272 & 0.039 & 0.796 \\
\hline PD & 0.606 & 0.611 & 0.150 & 0.959 \\
\hline $\mathrm{AM}$ & 0.724 & 0.823 & 0.010 & 0.979 \\
\hline \multicolumn{5}{|c|}{ Nitrate concentration, $N(\mathrm{mg} \mathrm{N} / \mathrm{L})$} \\
\hline $\mathrm{CP}$ & 1.03 & 0.45 & 0.09 & 4.40 \\
\hline PD & 3.41 & 2.94 & 0.26 & 7.93 \\
\hline $\mathrm{AM}$ & 1.90 & 1.10 & 0.06 & 6.04 \\
\hline
\end{tabular}

Relative removal potential:

$$
\frac{\left(\beta_{\mathrm{u}}+\beta_{\mathrm{up}} P_{\mathrm{p}}+\beta_{\mathrm{ua}} P_{\mathrm{a}}\right)}{\left(\beta_{\mathrm{c}}+\beta_{\mathrm{cp}} P_{\mathrm{p}}+\beta_{\mathrm{ca}} P_{\mathrm{a}}+\beta_{\mathrm{u}}+\beta_{\mathrm{up}} P_{\mathrm{p}}+\beta_{\mathrm{ua}} P_{\mathrm{a}}\right)}
$$

where Eq. 12 is Eq. 9 divided by Eq. 11 and the coefficients $(\beta)$ and dummy variables $(P)$ are as described for Eq. 1. The SAS GLM procedure provided standard error estimates for Eqs. 9, 10, and 11. We used error propagation (Bevington 1969) to estimate the standard error of relative removal potential (Eq. 12) from the model parameters and the parameter variances and covariances. Results from Eqs. 9-12 for the three buffer models (BF, $\mathrm{BFp}$, and $\mathrm{BFp}+$ ) were averaged using Akaike weights to estimate MA model values and their standard errors (Eq. 6.12 in Burnham and Anderson 2002).

\section{Nitrate sources and buffer nitrate removal in the study watersheds}

The fitted buffer model can be applied to the land cover proportions and physiographic province for any watershed to predict its stream nitrate concentration. This also estimates nitrate sources, nitrate removal by current buffers, and additional nitrate removal after complete buffer restoration for that watershed. Rearranging Eq. 7 and adding terms to represent the nitrate removed by current buffers gives an equation

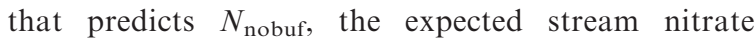
concentration from current land cover if there were no buffers on cropland:

$$
\begin{aligned}
N_{\text {nobuf }}= & \underbrace{\beta_{0}+\beta_{0 \mathrm{p}} P_{\mathrm{p}}+\beta_{0 \mathrm{a}} P_{a}+\beta_{\mathrm{g}} G+\beta_{\mathrm{d}} D}_{\mathrm{N}_{\mathrm{l}}, \text { non-crop sources }} \\
& +\underbrace{\left(\beta_{\mathrm{c}}+\beta_{\mathrm{cp}} P_{\mathrm{p}}+\beta_{\mathrm{ca}} \mathrm{P}_{\mathrm{a}}\right) C}_{\mathrm{N}_{2}, \text { buffer leakage }} \\
& +\underbrace{\left(\beta_{\mathrm{u}}+\beta_{\mathrm{up}} P_{\mathrm{p}}+\beta_{\mathrm{ua}} P_{\mathrm{a}}\right) C_{\mathrm{u}}}_{\mathrm{N}_{3}, \text { restoration removal }} \\
& +\underbrace{\left(\beta_{\mathrm{u}}+\beta_{\mathrm{up}} P_{\mathrm{p}}+\beta_{\mathrm{ua}} P_{\mathrm{a}}\right) C_{\mathrm{b}}}_{\mathrm{N}_{4}, \text { current removal }}+\varepsilon .
\end{aligned}
$$

The terms of Eq. 13 are arranged into four groups, and summing within each group estimates one of the four named components of the total predicted nitrate concentration if there were no buffers. We implemented these calculations for every study watershed and averaged the study watersheds in each province to yield province means of nitrate components. Combinations of these components are presented and interpreted in the Results section, including sums that give the predicted stream nitrate concentrations for four specific land cover scenarios $\left(N_{1}\right.$ no cropland, $N_{1}+N_{2}$ restored buffers, $N_{1}$ $+N_{2}+N_{3}$ current buffers, and $N_{1}+N_{2}+N_{3}+N_{4}$ no buffers). For these four scenarios, we used the MA model to estimate the standard error (and 95\% confidence limits) of the mean prediction (STDP option, GLM procedure; SAS Institute 2004) for province mean land cover. We did not calculate confidence limits for nitrate components that cannot be represented as predictions for specific land cover values because the model procedure does not estimate standard errors for those quantities.

\section{RESUlts}

\section{Land cover, buffer metrics, and nitrate concentrations}

The land cover patterns of the study watersheds differed among physiographic province (Table 1). Average cropland proportions were greatest in the Coastal Plain but the median value was greatest in the Piedmont. Developed land was also greatest in Coastal Plain study watersheds. Appalachian Mountain study watersheds had the lowest amounts of both cropland and developed land. Grasslands were far less common in Coastal Plain than in Piedmont or Appalachian study watersheds.

Buffer metrics also differed strongly among physiographic provinces (Table 1). Watershed mean buffer 


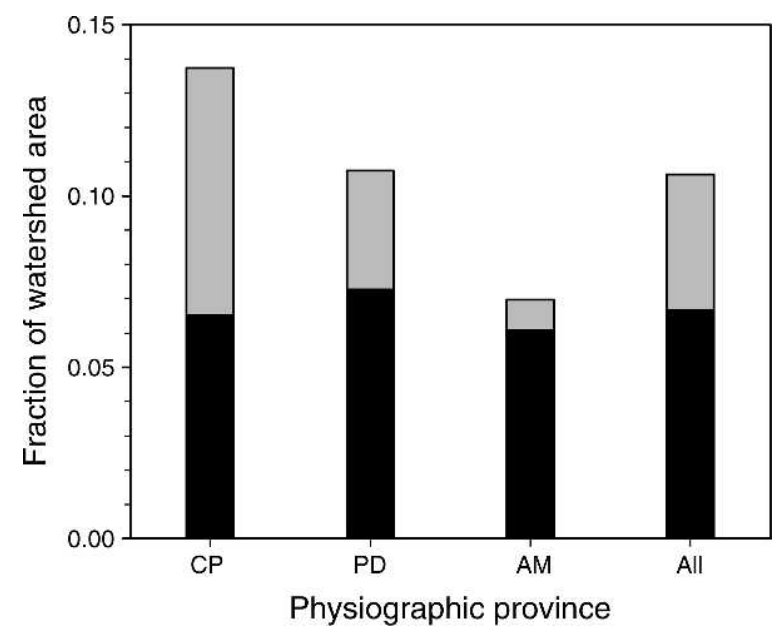

FIG. 3. Province average cropland proportions in the study watersheds. The average fraction of watershed occupied by unbuffered cropland (black) is the province average of buffer gap fraction for cropland $\left(\mathrm{FGAP}_{\mathrm{c}}\right)$ times the proportion of all cropland (Eq. 5) in each watershed. The upper portion of each bar is buffered cropland (gray), and the top of a bar gives the province average total cropland proportion. Key to provinces: CP, Coastal Plain; PD, Piedmont; AM, Appalachian Mountain.

width $\left(\mathrm{MBW}_{\mathrm{c}}\right)$ was greatest in the Coastal Plain and intermediate in the Piedmont, but a skewed distribution in the Appalachian Mountains gave a large average with a low median value. Gap frequency $\left(\mathrm{FGAP}_{\mathrm{c}}\right)$ was highest among Appalachian Mountain study watersheds (71\%), intermediate in the Piedmont (59\%), and lowest in the Coastal Plain (31\%).

The mean inverse buffer width for flow paths originating in croplands $\left(\mathrm{MIBW}_{\mathrm{c}}\right)$ was redundant with the gap fraction metric $\left(\mathrm{FGAP}_{\mathrm{c}}\right)$ because of the resolution of the land cover data (see Discussion). Values of $\mathrm{MIBW}_{\mathrm{c}}$ were roughly equal to the values of FGAP $_{\mathrm{c}}$ (Table 1), and $\mathrm{MIBW}_{\mathrm{c}}$ was very strongly correlated with $\mathrm{FGAP}_{\mathrm{c}}(R>0.998)$ within each province (Appendix: Table A1). We used $\mathrm{FGAP}_{\mathrm{c}}$ to provide buffer prevalence estimates for statistical models. Multiplying $\mathrm{FGAP}_{\mathrm{c}}$ by cropland proportion gave the proportion of unbuffered cropland (Table 1, Fig. 3). The average amount of unbuffered cropland in study watersheds was quite similar among provinces (6$7 \%$ of watershed area, Fig. 3), but the Coastal Plain watersheds had much more buffered cropland (roughly twice the average in the Piedmont and almost eight times the average of the Appalachian Mountains).

Despite high cropland and developed land proportions, Coastal Plain study watersheds had the lowest average stream nitrate concentrations (Table 1). Piedmont watersheds, which contained intermediate amounts of cropland, developed land, and grassland, had the greatest average stream nitrate concentrations. Appalachian Mountain watersheds had intermediate nitrate concentrations despite low amounts of cropland and developed land.

\section{Statistical models}

Land proportion models.-The land proportion (LP) model (Eq. 2) explained $73.6 \%$ of the variation in nitrate concentration among watersheds (Table 2) and described strong differences among provinces in the expected stream nitrate for given amount of watershed cropland (Table 3). The model coefficients for cropland showed that Piedmont study watersheds had greater expected nitrate concentrations per unit watershed proportion in cropland (31.0 $\mathrm{mg} \mathrm{N} / \mathrm{L}$, Table 3, Fig. 4) than either Appalachian Mountain (19.0 mg N/L) or Coastal Plain (7.7 mg N/L) study watersheds. Coefficients for developed land and grassland indicated relatively minor contributions to stream nitrate concentrations $(<0.8 \mathrm{mg} \mathrm{N} / \mathrm{L})$. Developed land $\left(F_{1,313}=1.26\right.$, $P=0.26)$ and grassland $\left(F_{1,313}=2.34, P=0.13\right)$ were not statistically significant given the other variables in the model, and eliminating them gave a more parsimonious land proportion model (LPp, Table 2). The low magnitude and lack of statistical significance for the developed land and grassland effects supported our decision to focus on buffers downhill from croplands, but these non-significant coefficients should not be applied in other contexts to estimate the nitrate contributions from developed land and grasslands. The LPp model explained $73.3 \%$ of the variation in

TABLE 2. Independent variables and performance measures used in models predicting stream nitrate concentrations from land cover proportions and physiographic province only (Eq. 2) and for models that also account for riparian buffers.

\begin{tabular}{|c|c|c|c|c|c|c|c|c|c|c|c|c|c|c|}
\hline \multirow[b]{2}{*}{ Model } & \multirow[b]{2}{*}{ Symbol } & \multicolumn{7}{|c|}{ Independent variables } & \multirow[b]{2}{*}{$R^{2}$} & \multirow[b]{2}{*}{ SSE } & \multirow[b]{2}{*}{$k$} & \multirow[b]{2}{*}{$\mathrm{AIC}_{\mathrm{c}}$} & \multirow[b]{2}{*}{$\Delta$} & \multirow{2}{*}{$\begin{array}{l}\text { Akaike } \\
\text { weight }\end{array}$} \\
\hline & & $C$ & $C \times P$ & $P$ & $D$ & $G$ & $C_{\mathrm{u}}$ & $C_{\mathrm{u}} \times P$ & & & & & & \\
\hline Land proportion & LP & $\mathrm{X}$ & $\mathrm{X}$ & $\mathrm{X}$ & $\mathrm{X}$ & $\mathrm{X}$ & & & 0.736 & 518.4 & 9 & 172.4 & 23.85 & 0.000 \\
\hline Parsimonious land proportion & LPp & $\mathrm{X}$ & $\mathrm{X}$ & $\mathrm{X}$ & & & & & 0.733 & 523.6 & 7 & 171.4 & 22.83 & 0.000 \\
\hline Buffer & $\mathrm{BF}$ & $\mathrm{X}$ & $\mathrm{X}$ & $\mathrm{X}$ & $\mathrm{X}$ & $\mathrm{X}$ & $\mathrm{X}$ & $\mathrm{X}$ & 0.755 & 480.9 & 12 & 154.7 & 6.14 & 0.034 \\
\hline Parsimonious buffer & BFp & $\mathrm{X}$ & $\mathrm{X}$ & & & & $\mathrm{X}$ & & 0.750 & 490.9 & 6 & 148.6 & 0.00 & 0.727 \\
\hline $\begin{array}{l}\text { Parsimonious buffer } \\
\quad \text { plus } C_{\mathrm{u}} \times P \text { interaction }\end{array}$ & $\mathrm{BFp}+$ & $\mathrm{X}$ & $\mathrm{X}$ & & & & $\mathrm{X}$ & $\mathrm{X}$ & 0.752 & 487.8 & 8 & 150.8 & 2.22 & 0.239 \\
\hline
\end{tabular}

Notes: $\mathrm{X}$ indicates that a particular variable was used in that model. Buffer models (Eq. 7) include the proportion of unbuffered cropland, which was calculated from total cropland and the buffer gap fraction (Eq. 5). $P$ is a dummy variable representing the categorical variable physiographic province, SSE is the error sum of squares, $k$ is the number of model parameters estimated (including residual model error), and $\Delta$ is the difference between $\mathrm{AIC}_{\mathrm{c}}$ and the $\mathrm{AIC}_{\mathrm{c}}$ of the best (BFp) model. 
TABLE 3. Coefficients for five models predicting stream nitrate concentrations and for the average of the five models (MA, weighted by Akaike weights, Table 2).

\begin{tabular}{|c|c|c|c|c|c|c|c|}
\hline $\begin{array}{c}\text { Model } \\
\text { component }\end{array}$ & Coefficient & LP & LPp & $\mathrm{BF}$ & BFp & $\mathrm{BFp}+$ & $\begin{array}{c}\text { Model } \\
\text { average (MA) }\end{array}$ \\
\hline \multicolumn{8}{|l|}{ Intercept } \\
\hline $\mathrm{CP}$ & $\beta_{0}$ & $-0.28(0.23)$ & $-0.03(0.17)$ & $0.00(0.24)$ & $\mathbf{0 . 3 5}(0.10)$ & $0.35(0.10)$ & $\mathbf{0 . 3 4}(0.13)[0.09,0.59]$ \\
\hline PD & $\beta_{0}+\beta_{0 p}$ & $-0.26(0.27)$ & $0.05(0.20)$ & $0.00(0.27)$ & $0.35(0.10)$ & $0.35(0.10)$ & $0.34(0.13)[0.08,0.60]$ \\
\hline $\mathrm{AM}$ & $\beta_{0}+\beta_{0 \mathrm{a}}$ & $0.29(0.22)$ & $0.53(0.17)$ & $0.35(0.22)$ & $0.35(0.10)$ & $0.35(0.10)$ & $\mathbf{0 . 3 5}(0.11)[0.14,0.57]$ \\
\hline \multicolumn{8}{|c|}{ Developed land and grassland } \\
\hline$D$ & $\beta_{\mathrm{d}}$ & $0.77(0.69)$ & & $0.59(0.67)$ & & & $0.02(0.16)[-0.30,0.34]$ \\
\hline$G$ & $\beta_{\mathrm{g}}$ & $0.66(0.43)$ & & $0.55(0.42)$ & & & $0.02(0.13)[-0.23,0.27]$ \\
\hline \multicolumn{8}{|l|}{ Cropland } \\
\hline $\mathrm{CP}$ & $\beta_{\mathrm{c}}$ & $7.74(0.93)$ & $7.68(0.86)$ & $2.02(1.89)$ & $0.36(1.42)$ & $0.94(1.58)$ & $0.56(1.52)[-2.44,3.55]$ \\
\hline PD & $\beta_{\mathrm{c}}+\beta_{\mathrm{cp}}$ & $30.96(1.58)$ & $31.36(1.54)$ & $20.03(3.52)$ & $21.93(1.93)$ & $19.14(3.04)$ & $\mathbf{2 1 . 2 0}(2.61)[16.07,26.33]$ \\
\hline $\mathrm{AM}$ & $\beta_{\mathrm{c}}+\beta_{\mathrm{ca}}$ & $18.98(1.56)$ & $19.67(1.49)$ & $14.71(8.63)$ & $11.26(2.31)$ & $\mathbf{1 8 . 0 6}(8.42)$ & $13.00(5.64)[1.91,24.09]$ \\
\hline \multicolumn{8}{|c|}{ Unbuffered cropland } \\
\hline $\mathrm{CP}$ & $\beta_{\mathrm{u}}$ & & & $\mathbf{8 . 5 2}(2.45)$ & $10.42(1.98)$ & $9.43(2.34)$ & $\mathbf{1 0 . 1 2}(2.15)[5.89,14.35]$ \\
\hline PD & $\beta_{\mathrm{u}}+\beta_{\mathrm{up}}$ & & & $13.47(3.91)$ & $10.42(1.98)$ & $14.29(3.79)$ & $11.45(3.11)[5.34,17.56]$ \\
\hline $\mathrm{AM}$ & $\beta_{\mathrm{u}}+\beta_{\mathrm{ua}}$ & & & $4.78(9.26)$ & $\mathbf{1 0 . 4 2}(1.98)$ & $2.88(9.19)$ & $8.43(6.05)[-3.48,20.33]$ \\
\hline \multicolumn{8}{|c|}{ Total from unbuffered cropland (Eq. 10) } \\
\hline $\mathrm{CP}$ & $\beta_{\mathrm{c}}+\beta_{\mathrm{u}}$ & & & $\mathbf{1 0 . 5 4}(1.20)$ & $10.78(1.01)$ & $10.37(1.15)$ & $\mathbf{1 0 . 6 8}(1.07)[8.57,12.78]$ \\
\hline PD & $\beta_{\mathrm{c}}+\beta_{\mathrm{cp}}+\beta_{\mathrm{u}}+\beta_{\mathrm{up}}$ & & & $33.49(1.70)$ & $32.35(1.13)$ & $33.44(1.43)$ & $32.65(1.32)[30.05,35.25]$ \\
\hline $\mathrm{AM}$ & $\beta_{\mathrm{c}}+\beta_{\mathrm{ca}}+\beta_{\mathrm{u}}+\beta_{\mathrm{ua}}$ & & & $19.49(1.70)$ & $21.68(1.26)$ & $20.94(1.53)$ & $21.43(1.43)[18.62,24.24]$ \\
\hline
\end{tabular}

Notes: The $\beta$ values are fitted model coefficients. The first subscript on a coefficient $\beta$ represents the land cover to which that coefficient applies (c, g, d, or u for cropland, grassland, developed land, or unbuffered cropland; 0 for background). If present, the second subscript represents the dummy variable for physiographic province to which the coefficient applies ("p" or "a" for $P$ p or $\left.P_{\mathrm{a}}\right)$. Standard errors are in parentheses, and $95 \%$ confidence limits for the MA coefficients are in brackets. Coefficients in boldface type are statistically different from zero $(P<0.05)$. In the BFp model, a single coefficient $\beta_{\mathrm{u}}$ applied to all three provinces. All coefficients have units of $\mathrm{mg} \mathrm{N} / \mathrm{L}$ per watershed proportion.

watershed nitrate concentrations and showed a minor improvement in $\mathrm{AIC}_{\mathrm{c}}(\Delta<2)$ compared to the LP model. Cropland coefficients did not differ substantially between the LP and LPp models (Table 3).

Buffer models and model evaluation.-Accounting for riparian buffer prevalence with the buffer model (BF, Eq. 7) explained more of the variance in nitrate concentrations $(75.5 \%)$ and substantially lowered $\mathrm{AIC}_{\mathrm{c}}$ $\left(\Delta \mathrm{AIC}_{\mathrm{c}}>17\right.$, Table 2$)$ compared to the LP model (Eq. $2)$. Developed land $\left(F_{1,310}=0.77, P=0.38\right)$ and grassland $\left(F_{1,310}=1.76, P=0.19\right)$ were again not statistically significant and were dropped. We also dropped province $\left(F_{2,310}=1.16, P=0.31\right)$ and the interaction of province with unbuffered cropland $\left(F_{2,310}\right.$ $=0.72, P=0.49$ ) because they were also not significant. This gave a parsimonious version of the buffer model (BFp), which explained $75.0 \%$ of variation in nitrate concentration and had a substantially lower $\mathrm{AIC}_{\mathrm{c}}$ than the LPp model $\left(\Delta \mathrm{AIC}_{\mathrm{c}}>20\right)$. Values of $\Delta \mathrm{AIC}_{\mathrm{c}}>10$ indicate essentially no empirical support (Burnham and Anderson 2002) for weaker land proportion models (LP or LPp) compared to the buffer models (BF or BFp).

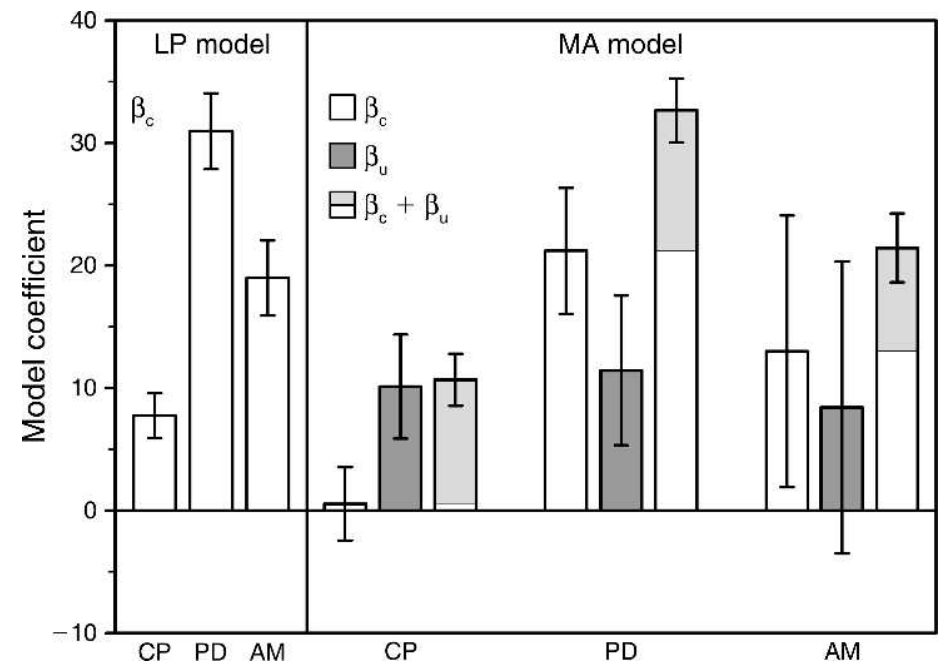

FIG. 4. Values and $95 \%$ confidence limits for coefficients of the land proportion model (LP, Eq. 2) and MA models (MA, Eq. 7). Coefficients have units of $\mathrm{mg} \mathrm{N} / \mathrm{L}$ per unit of watershed proportion occupied by cropland. Cropland coefficients apply to all cropland in both the LP and MA models and also represent buffer leakage (Eq. 10) in the MA model. The MA model also has a coefficient for the additional nitrate lost from unbuffered cropland, and this coefficient measures absolute nitrate removal potential (Eq. 9). The sum of the cropland and unbuffered cropland coefficients measures input from cropland to buffers and output from unbuffered cropland to streams (Eq. 11). Coefficients for developed land and grassland (not shown) are low and not statistically significant (Table 3 ). Key to province abbreviations: CP, Coastal Plain; PD, Piedmont; AM, Appalachian Mountain. 
Although the parsimonious buffer model (BFp) was more strongly supported than the full buffer model (BF, $\Delta \mathrm{AIC}_{\mathrm{c}}>6$ ), it was unclear whether the interaction between province and unbuffered cropland should be excluded, because much of the reduction in $\mathrm{AIC}_{\mathrm{c}}$ relative to the $\mathrm{BF}$ model came from eliminating grassland and developed land. To generate an $\mathrm{AIC}_{\mathrm{c}}$ comparison focused on whether or not unbuffered cropland effects differ among provinces, we restored the interaction of unbuffered cropland-province interaction to the BFp model to obtain an augmented parsimonious buffer model (BFp+) that assumes different buffer effects in the three provinces. This model accounted for $75.2 \%$ of the variation in nitrate concentration and had a moderate increase in $\mathrm{AIC}_{\mathrm{c}}\left(\Delta \mathrm{AIC}_{\mathrm{c}}=2.22\right.$, Table 2$)$ relative to the $\mathrm{BFp}$ model. The $\triangle \mathrm{AIC}_{\mathrm{c}}$ value near two suggests that both the $\mathrm{BFp}$ and $\mathrm{BFp}+$ models have substantial empirical support (Burnham and Anderson 2002), and neither should be rejected.

Model average.-The final model set included three models with buffer terms (BF, BFp, and $\mathrm{BFp}+$ ) and two models that did not account for buffers (LP and LPp). We used a weighted model average (MA) of the five candidate models for interpreting and applying the buffer model. With its Akaike weight of 0.73 , the BFp was roughly three times as likely to be the correct model and had three times the effect on the MA model as the $\mathrm{BFp}+$ model (Akaike weight $=0.24)$. The BF model had a very small contribution to the MA model (weight $=$ 0.03 ), while models lacking buffer effects (LP, LPp) had essentially no empirical support and contributed nothing to the MA model (weights $<0.0001$, Table 3 ). The MA model accounted for $75.1 \%$ of the variation in overall nitrate concentrations, and some outlying concentrations in the Piedmont and Appalachian Mountain watersheds were poorly predicted (Fig. 5).

Collinearity analysis. - Collinearity diagnostics indicated that correlations among the independent variables caused no numerical problems in any province and no interpretative problems for the Coastal Plain and Piedmont study watersheds (Appendix: Tables A2 and A3). The very high $C-C_{\mathrm{u}}$ correlation among the Appalachian Mountain study watersheds $(r=0.996)$ did lead to inflated standard errors for Appalachian Mountain cropland parameters (Table 3). Those parameter estimates are still unbiased (Appendix), but the large uncertainties limit their interpretation (next section). All the models perform nearly as well in predicting novel observations as in predicting the observations used in model development (see cross validation analysis; Appendix: Table A4). This further supports the quality of the models and demonstrates that collinearity did not cause problems in predicting observations not used in model fitting.

\section{Nitrate source and buffer nitrate removal potentials}

For each province, model average (MA) coefficients quantify the nitrate source strengths (per unit watershed

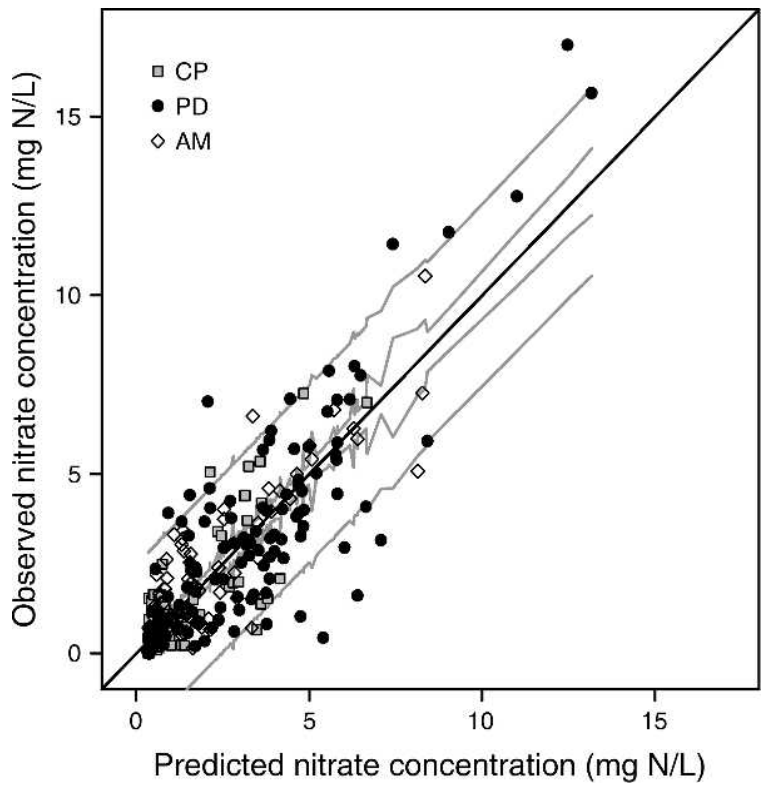

FIG. 5. Observed stream nitrate concentrations vs. model average (MA) predictions for all study watersheds. The solid line indicates 1:1 correspondence, and the gray lines indicate 95\% confidence for the population mean (inner band) and for 95\% confidence limits for an individual watershed prediction (outer band). Key to provinces: CP, Coastal Plain; PD, Piedmont; AM, Appalachian Mountain.

proportion) of different cover types and the nitrate removal potential of riparian buffers that are downhill from cropland (Table 3, Fig. 4). In all provinces, the rate of nitrate release from buffered croplands (Eq. 10) is lower than from unbuffered cropland (Eq. 11), although the difference was not significant for the Appalachian Mountain study watersheds because of high uncertainty in the parameter estimates. The total rate of nitrate release from unbuffered cropland (Eq. 11, Table 3) is highest in the Piedmont study watersheds $(32.7 \pm 1.32$ $\mathrm{mg} \mathrm{N} / \mathrm{L}$; mean $\pm \mathrm{SE}$ ), intermediate in Appalachian Mountain $(21.4 \pm 1.43 \mathrm{mg} \mathrm{N} / \mathrm{L})$, and lowest in the Coastal Plain $(10.7 \pm 1.07 \mathrm{mg} \mathrm{N} / \mathrm{L})$; and the pairwise differences among these rates are all statistically significant. The losses from buffered croplands (Eq. 10) also follow the order Piedmont $>$ Appalachian Mountain > Coastal Plain. The Piedmont loss $(21.1 \mathrm{mg}$ $\mathrm{N} / \mathrm{L}$ ) is significantly higher than the Coastal Plain loss $(0.56 \mathrm{mg} \mathrm{N} / \mathrm{L})$, but the high uncertainty for the Appalachian Mountain study watersheds (13.0 mg N/ L; $95 \%$ CI: 1.9, 24.1) make that estimate not statistically different from either the Piedmont or Coastal Plain estimates. The loss from Coastal Plain buffered cropland is not significantly different from zero ( $95 \%$ CI: 2.43 , 3.6) despite a low standard error because the coefficient itself is very close to zero (Table 3). Buffered croplands in Piedmont watersheds supply significantly more nitrate per unit watershed proportion $(21.2 \mathrm{mg} \mathrm{N} / \mathrm{L} ; 95 \% \mathrm{CI}$ : $16.1,26.3)$ than do unbuffered croplands in the Coastal Plain (10.7 mg N/L; 95\% CI: 8.6, 12.8). 


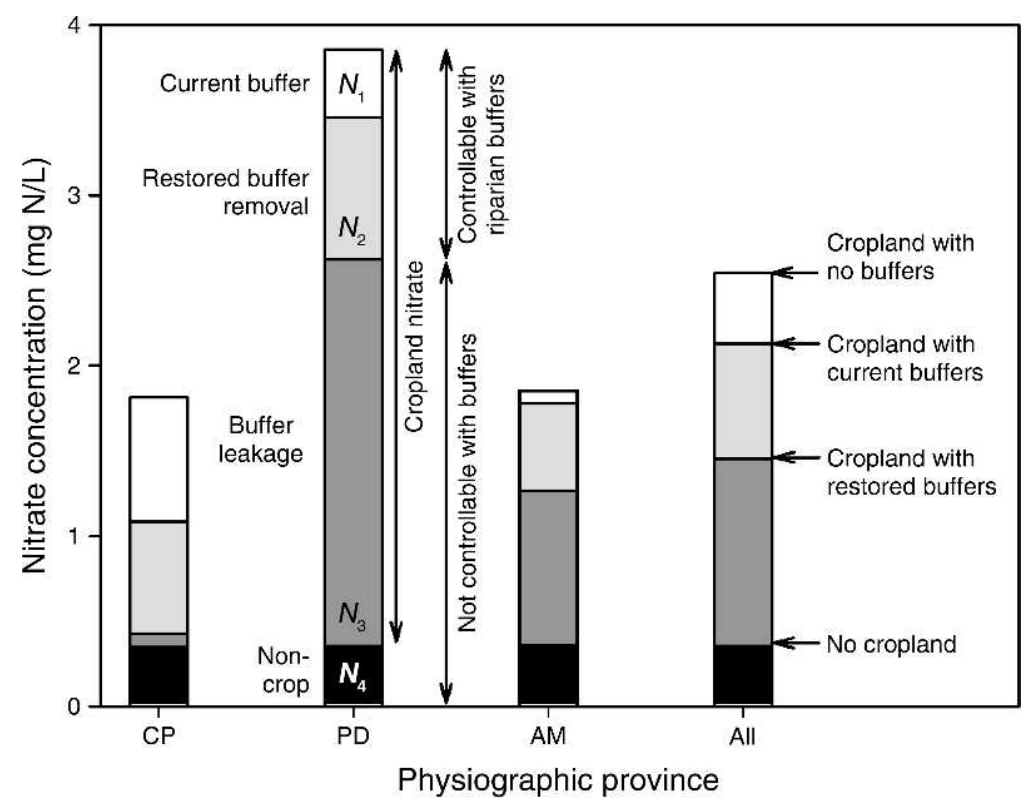

FIG. 6. Province averages of the components of predicted stream nitrate for the study watersheds. Text near the Piedmont (PD) bar labels the four components $\left(N_{1}-N_{4}\right.$, Eq. 13) and three quantities from summing those components (Table 4). The text at the right of the panel identifies average predicted stream nitrate concentrations with no cropland and with cropland under three scenarios of different buffer prevalence. Key to provinces: CP, Coastal Plain; AM, Appalachian Mountain; All, the average of all the study watersheds.

We applied Eq. 9 to the MA model parameters to estimate the absolute rate of nitrate removal in riparian buffers (Table 3), and this rate is higher in the Piedmont study watersheds $(11.5 \mathrm{mg} \mathrm{N} / \mathrm{L})$ than in the Coastal Plain (10.1 mg N/L) or Appalachian Mountains ( $8.4 \mathrm{mg} \mathrm{N} / \mathrm{L}$ ). The difference between buffers in the Coastal Plain $(95 \%$ CI: 5.5, 14.3) and Piedmont $(95 \%$ CI: 5.3, 17.6) study watersheds is not statistically significant, and the absolute removal rate for the Appalachian Mountain study watersheds was not significantly different from zero (95\% CI: -3.5 , 20.3) because of its high uncertainty. The high absolute removal in the Piedmont is partly due to the high input to buffers from croplands $(32.7 \mathrm{mg} \mathrm{N} / \mathrm{L}$ in the Piedmont study watersheds compared to 10.7 in the Coastal Plain). Expressed as fractions of input to buffers (Eq. 12), the average relative removal potential is much higher in the Coastal Plain study watersheds $(0.95 \pm 0.13)$ than in the Piedmont $(0.35 \pm 0.06)$ or Appalachian Mountains $(0.39 \pm 0.22)$. The relative removal fraction is significantly different from zero for the Coastal Plain (95\% CI: 0.07, 1.20) and Piedmont (95\% CI: $0.23,0.47)$ study watersheds, but relative removal for the Coastal Plain is not significantly different from 1.0 (complete removal). The estimated relative removal fraction in the Appalachian Mountain study watersheds (0.39) is not significantly different from zero because of its high uncertainty (95\% CI: $-0.05,0.83)$.

\section{Nitrate sources and buffer nitrate removal in the study watersheds}

We applied the MA model to the geographic data for each watershed to estimate four components of stream nitrate concentration (Eq. 13) and then calculated province means of these four components and other measures derived from them (Fig. 6, Table 4). Confidence limits of predicted stream nitrate concentration for specific land cover scenarios show that estimates for Appalachian Mountain study watersheds are more uncertain than for the Coastal Plain and Piedmont (Table 4); therefore, we have more confidence in the following results for Coastal Plain and Piedmont study watersheds than for Appalachian Mountain results.

Although study watersheds in the Coastal Plain have the highest average cropland proportion (Fig. 3), the average edge-of-field nitrate contribution from current cropland $\left(N_{2}+N_{3}+N_{4}\right.$, Fig. 6) is highest in the Piedmont (3.50 mg N/L) where loading per unit watershed proportion is highest (Fig. 4, Table 2). The edge-of-field contributions are roughly equal in the Coastal Plain and Appalachian Mountains (both almost $1.5 \mathrm{mg} \mathrm{N} / \mathrm{L}$ ) because the higher cropland nitrate loading rate per unit watershed proportion in the Appalachian Mountains offsets the lower cropland proportions there.

Province average nitrate removal by current buffers is highest in the Coastal Plain $(0.73 \mathrm{mg} \mathrm{N} / \mathrm{L}$ or $40 \%$ of the inputs from cropland) because the Coastal Plain study watersheds have much more cropland that is currently 
TABLE 4. Province means for components of stream nitrate in the study watersheds.

\begin{tabular}{|c|c|c|c|c|c|}
\hline \multirow[b]{2}{*}{ Component } & \multirow[b]{2}{*}{ Symbol } & \multicolumn{4}{|c|}{ Province } \\
\hline & & $\begin{array}{l}\text { Coastal } \\
\text { Plain }\end{array}$ & Piedmont & $\begin{array}{l}\text { Appalachian } \\
\text { Mountain }\end{array}$ & All \\
\hline \multicolumn{6}{|l|}{ Nitrate components } \\
\hline Non-crop sources & $N_{1}$ & $0.35[0.13,0.57]$ & $0.35[0.13,0.57]$ & $0.36[0.13,0.59]$ & 0.35 \\
\hline Buffer leakage & $\mathrm{N}_{2}$ & 0.08 & 2.27 & 0.91 & 1.10 \\
\hline Possible restoration removal & $N_{3}$ & 0.66 & 0.83 & 0.51 & 0.68 \\
\hline Current buffer removal & $N_{4}$ & 0.73 & 0.40 & 0.08 & 0.41 \\
\hline \multicolumn{6}{|l|}{ Sums of components } \\
\hline Not controllable by buffers & $N_{1}+N_{2}$ & $0.42[0.06,0.78]$ & $2.62[2.12,3.13]$ & $1.27[0.50,2.04]$ & 1.45 \\
\hline Controllable by buffers & $N_{3}+N_{4}$ & 1.39 & 1.23 & 0.59 & 1.09 \\
\hline Originating in cropland & $N_{2}+N_{3}+N_{4}$ & 1.47 & 3.50 & 1.49 & 2.19 \\
\hline \multicolumn{6}{|c|}{ Predicted stream nitrate concentration for specific scenarios } \\
\hline No cropland & $N_{1}$ & $0.35[0.13,0.57]$ & $0.35[0.13,0.57]$ & $0.36[0.13,0.59]$ & 0.35 \\
\hline With restoration of all buffer gaps & $N_{1}+N_{2}$ & $0.42[0.06,0.78]$ & $2.62[2.12,3.13]$ & $1.27[0.50,2.04]$ & 1.45 \\
\hline With current buffers & $N_{1}+N_{2}+N_{3}$ & $1.08[0.88,1.28]$ & $3.46[3.26,3.66]$ & $1.78[1.58,1.99]$ & 2.13 \\
\hline With no buffers & $N_{1}+N_{2}+N_{3}+N_{4}$ & $1.81[1.47,2.15]$ & $3.84[3.57,4.12]$ & $1.86[1.63,2.09]$ & 2.54 \\
\hline
\end{tabular}

Notes: The components (Fig. 6) are predicted from the geographic data for each watershed using Eq. 12 with model average (MA) coefficients (Table 3), and all components are in $\mathrm{mg} \mathrm{N} / \mathrm{L}$. The $95 \%$ confidence limits (in brackets) for specific land cover scenarios are 1.97 times the standard error of the mean prediction (STDP option, GLM procedure; SAS Institute 2004) for province mean land cover (Table 1). Confidence limits are not given for quantities that cannot be represented as predictions for specific land cover values because the model procedure does not estimate standard errors for those quantities.

buffered (Fig. 3) than do study watersheds in the other two provinces. Coastal Plain removal is almost twice the removal in the Piedmont $(0.40 \mathrm{mg} \mathrm{N} / \mathrm{L}, 10 \%$ of inputs from cropland, Table 4) and is about ten times greater than removal in Appalachian Mountain buffers (0.08 $\mathrm{mg} \mathrm{N} / \mathrm{L}, 4 \%$ of inputs), where removal potential (Fig. 4) and buffer prevalence (Fig. 3) are both low. Possible restoration nitrate removal is greatest in the Piedmont study watersheds, which have the highest watershed proportion of currently unbuffered cropland (the most restoration opportunities, Fig. 3) and the highest absolute buffer nitrate removal potential (Fig. 4). The Coastal Plain and Appalachian Mountain study watersheds currently have similar amounts of unbuffered cropland (Fig. 3), but complete restoration in the Appalachian Mountains would have a smaller effect on nitrate concentration because of the lower buffer nitrate removal potential in the Appalachian Mountains (Fig. 4).

Nitrate transmitted through buffers (buffer leakage) is very low in the Coastal Plain study watersheds $(0.1 \mathrm{mg}$ $\mathrm{N} / \mathrm{L}$ ), where buffers on average transmit only $5 \%$ of the inputs they receive from cropland (Table 3 ). The nitrate passed through buffers is highest in the Piedmont (2.27 $\mathrm{mg} \mathrm{N} / \mathrm{L}$ ) because buffers there transmit $65 \%$ of their very high inputs from cropland. Appalachian Mountain buffers pass intermediate amounts of nitrate $(0.91 \mathrm{mg}$ $\mathrm{N} / \mathrm{L}$ ) because cropland inputs and removal percentages there are both between Coastal Plain and Piedmont values.

Stream nitrate not controllable with cropland buffers $\left(N_{1}+N_{2}\right.$; Fig. 6), comes from non-cropland sources or cropland nitrate transmitted through riparian buffers. The uncontrollable portion is $29 \%$ of the maximum load in the Coastal Plain study watersheds, but a much larger percentage in the Piedmont (75\%) and Appalachian Mountain (85\%) provinces. The maximum scope of riparian buffers to reduce nitrate from cropland is 1.39 $\mathrm{mg} \mathrm{N} / \mathrm{L}$ (77\% of inputs from cropland) in Coastal Plain study watersheds, and lower in the Piedmont $(1.23 \mathrm{mg}$ $\mathrm{N} / \mathrm{L}, 32 \%$ of cropland inputs) and Appalachian Mountain watersheds $(0.59 \mathrm{mg} \mathrm{N} / \mathrm{L}, 32 \%$ of inputs). Although the percentage reduction was the same in the Piedmont and Appalachian Mountains, the absolute amount is higher in the Piedmont study watersheds because of the higher inputs to buffers from croplands Fig. 4, Table 3).

Across the entire set of study watersheds, current buffer patterns remove an average of $16 \%$ of the estimated cropland nitrate losses and reduce stream nitrate by $0.41 \mathrm{mg} \mathrm{N} / \mathrm{L}$ compared to the same watersheds with no buffers. Complete restoration has the potential to take out an additional $0.68 \mathrm{mg} \mathrm{N} / \mathrm{L}$, raising total removal of nitrate lost from cropland in the study watersheds to $1.09 \mathrm{mg} \mathrm{N} / \mathrm{L}$ (2.7 times the current buffer removal). This would lower average stream nitrate concentration from the current $2.13 \mathrm{mg} \mathrm{N} / \mathrm{L}$ to $1.45 \mathrm{mg} \mathrm{N} / \mathrm{L}$, a $32 \%$ reduction relative to the current average concentration (Table 4). Actual reductions would likely be less than these estimates because restored buffers may not retain nitrate as effectively as extant buffers (see below).

\section{DisCUSSION}

New evidence for buffer effects on watershed discharges

Our results demonstrate that buffers have an important effect on stream nitrate concentrations and must be considered to understand the controls of stream nitrate levels. Land proportion models lacking buffer informa- 
tion explained substantial amounts of variation in nitrate concentrations among watersheds but received essentially no empirical support when compared with the buffer models. Incorporating measures of buffer prevalence produced relatively small increases in explained variance $(\sim 2 \%)$ but very large reductions in $\mathrm{AIC}_{\mathrm{c}}\left(\Delta \mathrm{AIC}_{\mathrm{c}}>20\right)$ and far more likely (>10 000 times $)$ models (Table 2). We therefore concluded that the buffer models can and should be used to evaluate buffer nitrate removal potential and to quantify current cropland nitrate losses, current buffer nitrate removals, and the additional removals that might be achieved by buffer restoration.

Ours is the first analysis to clearly test the hypothesis that buffer information improves watershed-scale predictions of stream nitrate levels and then to apply a statistical watershed model to quantify nitrate removal in buffers. Previous watershed-scale studies have been limited by the geographic analyses used to map buffers and the statistical models used to test for and quantify buffer effects on stream nutrient levels. We implemented new approaches to overcome both challenges. We developed a geographic analysis that accounts for the prevalence of buffers along flow paths connecting source areas to streams (Weller et al. 1998, Baker et al. 2006a, 2007). The flow-path definition of buffer is conceptually more relevant than fixed-distance measures because integrating across flow pathways correctly "scales up" from transect observations to whole-watersheds (Baker et al. 2006a) and allows detection of systematic or nonlinear interactions between nutrient sources and potential sinks (Weller et al. 1998, Gergel 2005, Baker et al. 2007). Therefore, our flow path metrics provide better indication of buffer prevalence and the likely impacts on nitrate levels than do simpler measures, such as land cover proportions or fixed-distance measures of buffers used in previous studies (e.g., Omernik et al. 1981, Osborne and Wiley 1988, Johnson et al. 1997, Jones et al. 2001).

We also developed a new statistical approach to provide a more discerning test for buffer effects and to quantify nitrogen removal by buffers. Previous analyses used model equations that could not estimate nitrogen retention in buffers (e.g., Johnson et al. 1997, Jones et al. 2001). In those equations (and in our land proportion models), all cropland is lumped together. When buffered and unbuffered cropland are not resolved, the difference between their effects (i.e., buffer nutrient removal) cannot be calculated because both effects are averaged into a single model coefficient. In this case, added buffer terms can be significant only if they have a strong effect on the average nutrient loss from all cropland. Some previous studies reported that including a buffer term improved statistical models of stream nitrogen (Johnson et al. 1997, Norton and Fisher 2000, Baker et al. 2001, Jones et al. 2001), but the increases in explained variance were usually small and difficult to interpret objectively. It was often unclear whether the buffer term was a significant or useful addition (Johnson et al. 1997), especially when stepwise regression was used to select from a large number of candidate models. We used a priori knowledge to create just two initial models (Eqs. 2 and 7) that would clearly test the importance of buffer terms. Our buffer model relates nitrate levels to the proportions of both total and unbuffered cropland, so that simple manipulations of the parameters (Eqs. 9-12) and individual predictions (Eq. 13) gave clear estimates of nitrate removal with confidence limits. Finally, we applied information theoretic methods (Burnham and Anderson 2002), to demonstrate that models accounting for nitrate removal in buffers were superior to models based solely on land cover proportions.

The variability in stream nitrate concentrations explained by the buffer models was only slightly higher than the variability explained by the simple land proportion model ( $R^{2}$ values in Table 3$)$. The gain in $R^{2}$ is small because riparian buffer distributions are highly correlated with cropland distributions (Baker et al. 2007). Across our study area, the placements of croplands and riparian forests and wetlands are determined by the same set of controlling factors: rural lands that are relatively flat and not waterlogged tend to be farmed while lands that are steep or waterlogged tend to be left in natural vegetation. Topographic and hydrologic settings that support higher cropland proportions thus favor lower fractions of that cropland being buffered. Simple land proportion models can make good predictions of stream nitrate concentrations precisely because the proportions of total and unbuffered cropland are correlated so that one variable can almost replace two. With our present study watersheds, the main advantage of the buffer models is not more accurate predictions of stream nitrate concentrations, but rather better understanding of how nitrate sources and sinks interact to produce observed stream nitrate concentrations.

Including total and unbuffered cropland in our models did risk numerical and interpretative problems due to collinearity. We followed the recommendation of recent ecological and statistical analyses (O'Brien 2007, Smith et al. 2009) and many previous reports (Appendix) to include collinear variables when they are essential to the underlying conceptual model. Eliminating important variables to avoid collinearity creates biases in model parameters that are worse than the effects of collinearity (O'Brien 2007, Smith et al. 2009). Such a bias is evident in our land proportion models where the single loss rate from all cropland takes a value between the loss rates for buffered and unbuffered cropland in the buffer models, and a similar bias in cropland loss estimates is likely present in other models that do not separate buffered and unbuffered cropland (e.g., Johnson et al. 1997, Preston and Brakebill 1999, Alexander et al. 2000, Jones et al. 2001). Diagnostic assessment of our buffer models shows that collinearity was not a problem for the 
Coastal Plain or Piedmont study watersheds, but did cause high uncertainty in the cropland parameters for the Appalachian Mountain study watersheds (Appendix) as we have cautioned when interpreting those parameters in the Results and Discussion. By carefully selecting a different set of study watersheds to minimize the correlation between total cropland and unbuffered cropland, one might reduce collinearity and increase confidence in the model parameters. The buffer models would likely also show stronger improvements in $R^{2}$ relative to the land proportion models than we observed with our study watersheds.

Our watershed estimates of relative nitrate removal are lower than the percentage reductions reported by many published studies of field-to-stream transects (e.g., Lowrance et al. 1997, Mayer et al. 2007). Buffer effectiveness depends on placement downhill from nutrient sources and on inherent removal potential, which varies spatially and temporally (e.g., Baker et al. 2001, 2006a, McClain et al. 2003). Transect studies often offer an idealized view of buffer removal under optimal conditions (Dosskey 2001, Dosskey et al. 2002, Baker et al. 2007). Our watershed analysis integrates the prevalence of source areas, their nitrate source strength, the spatial patterns of buffers relative to sources, and buffer nitrate removal potential to offer more complete and realistic estimates of buffer performance.

\section{Directions for further research}

We have presented an advance in buffer analysis that could be further improved by better characterization of land cover patterns, flow paths, and variations in buffer nitrate removal. Our results depend on the accuracy of the land cover classification. Different classifications of the same landscape image can yield substantially different land cover maps and different results from statistical models of nitrate discharges (Weller et al. 2003, Claggett et al. 2010). Like any prediction based on land cover maps, our results are only as accurate as the input data.

Map resolution is also important. Transect studies suggest that buffer width is just as relevant for quantifying nitrogen removal as the presence of buffer gaps. However, both measures were functionally equivalent in our analysis because we used a 30-m land cover raster. At this resolution, the narrowest detectable buffer width is at best $15 \mathrm{~m}$ (O'Neill et al. 1996). Even though transect studies suggest that buffers less than $15 \mathrm{~m}$ wide are effective (Lowrance et al. 1997, Mayer et al. 2007), such narrow buffers could not be detected in our analysis of $30-\mathrm{m}$ land cover data. This is a limitation of the geospatial data, not our method. Our analysis can and should be applied to finer resolution information to improve buffer detection (Goetz 2006, Hollenhorst et al. 2006, Gergel et al. 2007) and to include the effects of narrower buffers in nitrate models. In the meantime, it would not be valid to apply buffer efficiencies from our analysis of 30-m land cover data to maps developed with high-resolution land cover sources. The removal efficiencies we report for relatively wide buffers downhill from croplands should not be applied to narrower buffers or to buffers that are not downhill from nutrient source areas. Geographic analyses of buffers are also sensitive to the spatial accuracy (Claggett et al. 2010) and level of detail (Baker et al. 2007) of the stream map, and our analysis should be repeated if more accurate or more detailed stream maps become available.

Our models make the simplifying assumption that water generally flows downhill. This enabled us to use available data in improved spatial models that successfully tested for buffer effects and quantified nitrate removal. Our analysis could certainly be improved by better information on the directions of both surface and subsurface flow. Finer resolution topographic data could improve knowledge of surface flow, but may require more sophisticated terrain analyses that allow flow in more than one downhill direction (e.g., Seibert and McGlynn 2007, Tarboton and Baker 2008). In addition, subsurface flow is an important source of stream nitrate and may be poorly related to surface topography (Bohlke and Denver 1995, Baker et al. 2001, Vidon and Hill 2004). Riparian buffers that seem well positioned according to surface topography can be ineffective when subsurface flow goes around the buffer or deep beneath the biologically active soils of the buffer zone (Denver 1991, Altman and Parizek 1995, Speiran 2010). Methods for quantifying key constraints on subsurface flow (e.g., Gerla 1999, Baker et al. 2003, Kellogg et al. 2008) could be incorporated to improve model results. Even without such improvements, we did observe strong and statistically significant buffer effects in the Coastal Plain and Piedmont study watersheds, which confirms that our simplifying assumptions are useful.

We tested our model using study watersheds from three physiographic provinces of the Chesapeake Bay drainage. Previous research reported differences among provinces in nitrate losses from croplands and nitrate removal in buffers (Jordan et al. 1997c, 2003, Liu et al. 2000), so we constructed our model to accommodate those differences. However, our study watersheds do not provide a representative random sample of each physiographic province. Our analysis confirms that there are important differences among provinces that must be accommodated, but our results do not provide unbiased representative estimates of buffer performance for each province. The analysis should be applied to more watersheds selected in a representative way to better quantify province means and within-province variations in nitrate sources from different land cover types and nitrate removal in buffers.

Our model currently represents average maximum nitrate removal potential by riparian buffers as a province-wide constant. Many factors can cause differences in buffer performance within provinces; including hydrologic setting; the amount, extent, and type of row 
crop agriculture; fertilizer application; atmospheric deposition; the resulting buffer nitrate inputs; and buffer vegetation (Altman and Parizek 1995, Jordan and Weller 1996, Jordan et al. 1997b,c, Liu et al. 2000, Vidon and Hill 2004, Baker et al. 2006a, Jenesco et al. 2009, Murphy et al. 2009, Dosskey et al. 2010, Newbold et al. 2010, Speiran 2010). Our model could be improved by incorporating spatial variability in nitrate removal, possibly by using additional mapped information and topographic analysis to delineate floodplains, valley bottoms, or other biogeochemically active areas (e.g., Phillips 1989, O'Neill et al. 1997, Baker et al. 2001, Gold et al. 2001, Rosenblatt et al. 2001, McGlynn and Seibert 2003, Tomer et al. 2003, 2009, Vidon and Hill 2004, Dosskey et al. 2005, Jenesco et al. 2009, Murphy et al. 2009, Vidon et al. 2010).

\section{Management implications}

Despite having similar $R^{2}$ values, models based on land proportion only and those including riparian buffers have profoundly different implications for evaluating watershed impacts. For example, the MA model predicts that, among our Coastal Plain study watersheds, unbuffered cropland contributes $90 \%$ of observed stream nitrate from cropland, even though it accounts for only $47 \%$ of total cropland area (Fig. 3). In contrast, the model based only on land proportion would attribute only $47 \%$ of the stream nitrate from cropland to unbuffered cropland. This difference represents a dramatic change in our perception of the spatial distribution of nutrient sources affecting water quality. We recommend that buffered and unbuffered cropland should be distinguished in widely applied regional models (e.g., SPARROW; Smith et al. 1997, Preston and Brakebill 1999, Alexander et al. 2000) as well as process-based simulations like the Chesapeake Bay watershed model (Linker et al. 2000).

Our models can help guide buffer restoration priorities for reducing nitrate inputs to Chesapeake Bay. Coastal Plain buffers are very efficient at absorbing nitrate (Table 3; Lowrance et al. 1984, 1997, Peterjohn and Correll 1984, Jordan et al. 1993), and buffer restorations there will clearly reduce nitrate delivery to the Bay (Table 4, Fig. 6). Piedmont and Appalachian Mountain buffers remove lower percentages of their inputs than Coastal Plain buffers (Table 4, Fig. 6; Newbold et al. 2010), possibly because existing buffers may be bypassed or dysfunctional in some Piedmont or Mountain settings (e.g., Jordan et al. 1997c, Lowrance et al. 1997, Craig et al. 2008). However, Piedmont buffers receive higher nitrate inputs from cropland and have the highest absolute nitrate removal potential (Table 4, Fig. 6), so widespread restoration in the Piedmont could have the largest aggregate effect on nitrate delivery to the Bay. Our Appalachian Mountain study watersheds suggest that buffer restoration there should have lower priority. Appalachian Mountain buffers have the lowest absolute nitrate removal potential (Table 3), and their discharges travel farther in streams and rivers where nutrients can be removed before reaching the Bay (Preston and Brakebill 1999, Alexander et al. 2000, Mulholland et al. 2008). However, additional Appalachian Mountain watersheds with more diverse patterns of cropland and buffer prevalence should be studied to reduce the large uncertainty in our nitrate removal parameters for Appalachian Mountain study watersheds (Table 3).

We estimated that restoring all buffer gaps downhill from croplands in our study watersheds could remove up to 2.7 times more nitrate than the current buffers (Table 4) and reduce average stream nitrate concentrations by $32 \%$. These numbers probably overestimate the restoration benefit because they assume that all buffer gaps downhill from croplands could be restored to achieve the nitrogen removal potential of current buffers. Present buffers often exist in areas that are steep, wet, or otherwise unsuitable for farming; and these may be better sites for nitrate removal than the cleared sites that are available for buffer restoration. Buffer performance also varies with site characteristics (see above), and restored buffers may take some time to recover nitrate removal capacities (Gregory et al. 2007, Gift et al. 2008, Newbold et al. 2010). Further studies of restored buffers would help clarify how quickly nitrate removal capacities develop and how the ultimate removal rates compare to those of current riparian buffers. Where buffer performance is lower, on-site management of nutrient source areas rather than just downhill buffers will be needed to reduce nutrients. Finally, many existing riparian land uses do not allow for buffer restoration (e.g., urbanization, impoundment, or tile drainage). Efforts to manage regional nitrogen losses should consider all of these realities when estimating the expected water quality benefits of riparian conservation and restoration.

\section{ACKNOWLEDGMENTS}

Support for this research was provided in part by grants from the U.S. Environmental Protection Agency's Science to Achieve Results (STAR) Estuarine and Great Lakes (EaGLes) Program to the Atlantic Slope Consortium (USEPA Agreement \#R-82868401) and the Watershed Classification Program (USEPA Agreement \#R-831369). Although the research described in this article has been funded by the U.S. Environmental Protection Agency, it has not been subjected to the Agency's required peer and policy review and therefore does not necessarily reflect the views of the Agency, and no official endorsement should be inferred. Further support was provided by CICEET, the Cooperative Institute for Coastal and Estuarine Environmental Technology. The stream data were collected with support from NSF (BSR-89-05219, DEB92-06811, and DEB-93-17968), NOAA (NA66RG0129), the Governor's Research Council of Maryland, the government of Charles County Maryland, and the Smithsonian Institution Environmental Sciences Program. David L. Correll led the stream sampling program. We thank Alison Baker, Kathy Boomer, Molly Van Appledorn, and Micah Ryder for detailed feedback on early versions of the manuscript. Doug Call, James Graves, Sal Orochena, Nancy Lee, Jennifer Bruggink, Carolyn Lieberman, Kieren Tinning, and Michelle Coffee assembled 
spatial data used in some of the analyses. D. E Weller and M. E. Baker are joint first authors.

\section{Literature Cited}

Alexander, R. B., R. A. Smith, and G. E. Schwarz. 2000. Effect of stream channel size on the delivery of nitrogen to the Gulf of Mexico. Nature 403:758-761.

Altman, S. J., and R. R. Parizek. 1995. Dilution of nonpointsource nitrate in groundwater. Journal of Environmental Quality 24:707-718.

Bachman, L., J. B. Lindsey, J. W. Brakebill, and D. S. Powars. 1998. Ground-water discharge and base-flow nitrate loads of nontidal streams, and their relation to a hydrogeomorphic classification of the Chesapeake Bay watershed, middle Atlantic coast. Water-Resources Investigations Report 984059. U.S. Geological Survey, Baltimore, Maryland, USA.

Baker, M. E., D. E. Weller, and T. E. Jordan. 2006a. Improved methods for quantifying potential nutrient interception by riparian buffers. Landscape Ecology 21:1327-1345.

Baker, M. E., D. E. Weller, and T. E. Jordan. $2006 b$. Comparison of automated watershed delineations: effects on land cover areas, percentages, and relationships to nutrient discharge. Photogrammetric Engineering and Remote Sensing 72:159-168.

Baker, M. E., D. E. Weller, and T. E. Jordan. 2007. Effects of stream map resolution on measures of riparian buffer distribution and nutrient retention potential. Landscape Ecology 22:973-992.

Baker, M. E., M. J. Wiley, and P. W. Seelbach. 2001. GISbased hydrologic modeling of riparian areas: implications for stream water quality. Journal of the American Water Resources Association 37:1615-1628.

Baker, M. E., M. J. Wiley, P. W. Seelbach, and M. L. Carlson. 2003. A GIS-based index of groundwater potential for aquatic resource inventory, assessment, and environmental management. Environmental Management 32:706-719.

Bevington, P. R. 1969. Data reduction and error analysis for the physical sciences. McGraw-Hill, New York, New York, USA.

Boesch, D. F., R. B. Brinsfield, and R. E. Magnien. 2001. Chesapeake Bay eutrophication: scientific understanding, ecosystem restoration, and challenges for agriculture. Journal of Environmental Quality 30:303-320.

Bohlke, J. K., and J. M. Denver. 1995. Combined use of groundwater dating, chemical, and isotopic analyses to resolve the history and fate of nitrate contamination in two agricultural watersheds, Atlantic Coastal Plain, Maryland. Water Resources Research 31:2319-2339.

Burnham, K. P., and D. R. Anderson. 2002. Models selection and multimodel inference: a practical information-theoretic approach. Springer, New York, New York, USA.

Carpenter, S. R., N. F. Caraco, D. L. Correll, R. W. Howarth, A. N. Sharpley, and V. H. Smith. 1998. Nonpoint pollution of surface waters with phosphorous and nitrogen. Ecological Applications 8:559-568.

Claggett, P. R., J. A. Okay, and S. V. Stehman. 2010. Monitoring regional riparian forest cover change using stratified sampling and multiresolution imagery. Journal of the. American Water Resources Association 46:334-343.

Cooper, A. B. 1990. Nitrate depletion in the riparian zone and stream channel of a small headwater catchment. Hydrobiologia 202:13-26.

Correll, D. L., T. E. Jordan, and D. E. Weller. 1997. Failure of agricultural riparian buffers to protect surface waters from groundwater nitrate contamination. Pages 162-165 in J. Gibert, J. Mathieu, and F. Fournier, editors. Groundwater/ surface water ecotones: biological and hydrological interactions and management options. Cambridge University Press, Cambridge, UK.
Craig, L. S., et al. 2008. Stream restoration strategies for reducing river nitrogen loads. Frontiers in Ecology and the Environment 6:529-538.

Day, R. L., and R. C. Crew. 2005. Chesapeake Bay riparian forest and wetland buffer inventory: final report. The Geospatial Technology Program at the Land Analysis Laboratory, Pennsylvania State University, University Park, Pennsylvania, USA.

Denver, J. M. 1991. Groundwater-sampling network to study agrochemical effects on water quality in the unconfined aquifer. Pages 139-149 in R. G. Nash and A. R. Leslie, editors. ACS Symposium Series \#465, Groundwater residue sampling design. American Chemical Society, Washington, D.C., USA.

Diebel, M., J. Maxted, D. Robertson, S. Han, and M. Vander Zanden. 2009. Landscape planning for agricultural nonpoint source pollution reduction III: assessing phosphorus and sediment reduction rotential. Environmental Management 43:69-83.

Dosskey, M. G. 2001. Toward quantifying water pollution abatement in response to installing buffers on crop land. Environmental Management 28:577-598.

Dosskey, M. G., D. E. Eisenhauer, and M. J. Helmers. 2005. Establishing conservation buffers using precision information. Journal of Soil and Water Conservation 60:349-354.

Dosskey, M. G., M. J. Helmers, D. E. Eisenhauer, T. G. Franti, and K. D. Hoagland. 2002. Assessment of concentrated flow through riparian buffers. Journal of Soil and Water Conservation 57:336-343.

Dosskey, M. G., P. Vidon, N. P. Gurwick, C. J. Allan, T. P. Duval, and R. Lowrance. 2010. The role of riparian vegetation in protecting and improving chemical water quality in streams. Journal of the American Water Resources Association 46:261-277.

Federal Leadership Committee for the Chesapeake Bay. 2010. Strategy for protecting and restoring the Chesapeake Bay watershed: Executive Order 13508. 〈http://executiveorder. chesapeakebay.net/file.axd?file=2010\%2f5\%2fChesapeake + EO+Strategy\%20.pdf $\rangle$

Freund, R. J., and P. D. Minton. 1979. Regression methods. Marcel Dekker, Inc., New York, New York, USA.

Gergel, S. E. 2005. Spatial and non-spatial factors: when do they impact the utility of landscape indicators of water quality? Landscape Ecology 20:177-189.

Gergel, S. E., Y. Stange, N. C. Coops, C. Bater, K. Johansen, and K. R. Kirby. 2007. What is the value of a good map? An example using high spatial resolution imagery to aid riparian restoration. Ecosystems 10:688-702.

Gerla, P. J. 1999. Estimating the ground-water contribution in wetlands using modeling and digital terrain analysis. Wetlands 19:394-402.

Gesch, D., M. Oimoen, S. Greenlee, C. Nelson, M. Steuck, and D. Tyler. 2002. The national elevation dataset. Photogrammetric Engineering and Remote Sensing 68:5-11.

Gift, D. M., P. M. Groffman, S. S. Kaushal, and P. M. Mayer. 2008. Denitrification potential, root biomass, and organic matter in degraded and restored urban riparian zones. Restoration Ecology 18:113-120.

Goetz, S. J. 2006. Remote sensing of riparian buffers: past progress and future prospects. Journal of the American Water Resources Association 42:133-143.

Gold, A. J., P. M. Groffman, K. Addy, D. Q. Kellogg, M. Stolt, and A. E. Rosenblatt. 2001. Landscape attributes as controls on groundwater nitrate removal capacity of riparian zones. Journal of the American Water Resources Association 37:1457-1464.

Gregory, S., A. Allen, M. Baker, K. Boyer, T. Dillaha, and J. Elliott. 2007. Realistic expectations of timing between conservation and restoration actions and ecological responses. Pages 115-146 in M. Schnepf and C. Cox, editors. 
Managing agricultural landscapes for environmental quality. Soil and Water Conservation Society, Ankeny, Iowa, USA.

Hagy, J. D., W. R. Boynton, C. W. Keefe, and K. V. Wood 2004. Hypoxia in Chesapeake Bay, 1950-2001: long-term change in relation to nutrient loading and river flow. Estuaries and Coasts 27:634-658.

Hassett, B., M. A. Palmer, E. S. Bernhardt, S. Smith, J. Carr, and D. D. Hart. 2005. Restoring watersheds project by project: trends in Chesapeake Bay tributary restoration. Frontiers in Ecology and the Environment 3:259-267.

Hefting, M. M., J. C. Clement, D. Dowrick, A. C. Cosandey, S. Bernal, C. Cimpian, A. Tatur, T. P. Burt, and G. Pinay. 2004 Water table elevation controls on soil nitrogen cycling in riparian wetlands along a European climatic gradient. Biogeochemistry 67:113-134.

Hill, A. R. 1996. Nitrate removal in stream riparian zones. Journal of Environmental Quality 25:743-755.

Hollenhorst, T. H., G. E. Host, and L. B. Johnson. 2006. Scaling issues in mapping riparian zones with remote sensing data: quantifying errors and sources of uncertainty. Pages 275-295 in J. Wu, K. B. Jones, H. Li, and O. L. Loucks, editors. Scaling and uncertainty analysis in ecology: methods and applications. Springer, Dordrecht, The Netherlands.

Jacobs, T. C., and J. W. Gilliam. 1985. Riparian loses of nitrate from agricultural drainage waters. Journal of Environmental Quality 14:472-478.

Jenesco, K. G., B. L. McGlynn, M. N. Gooseff, S. M. Wondzell, K. E. Bencala, and L. A. Marshall. 2009. Hydrologic connectivity between landscapes and streams: transferring reach- and plot-scale understanding to the catchment scale. Water Resources Research 45:W04428. [doi:10.1029/2008WR007225]

Johnson, L. B., C. Richards, G. E. Host, and J. W. Arthur. 1997. Landscape influences on water chemistry in Midwestern stream ecosystems. Freshwater Biology 37:193-208.

Jones, K. B., A. C. Neale, M. S. Nash, R. D. Van Remortel, J. D. Wickham, K. H. Riiters, and R. V. O'Neill. 2001. Predicting nutrient discharges and sediment loadings to streams from landscape metrics: a multiple watershed study from the United States Mid-Atlantic Region. Landscape Ecology 16:301-312.

Jordan, T. E., D. L. Correll, and D. E. Weller. 1993. Nutrient interception by a riparian forest receiving cropland runoff. Journal of Environmental Quality 22:467-473.

Jordan, T. E., D. L. Correll, and D. E. Weller. 1997a. Effects of agriculture on discharges of nutrients from Coastal Plain watersheds of Chesapeake Bay. Journal of Environmental Quality 26:836-848.

Jordan, T. E., D. L. Correll, and D. E. Weller. 1997b. Nonpoint source discharges of nutrient from Piedmont watersheds of Chesapeake Bay. Journal of the American Water Resources Association 33:631-645.

Jordan, T. E., D. L. Correll, and D. E. Weller. 1997c. Relating nutrient discharges from watersheds to land use and streamflow variability. Water Resources Research 33:2579-2590.

Jordan, T. E., and D. E. Weller. 1996. Human contributions to terrestrial nitrogen flux. BioScience 46:655-664.

Jordan, T. E., D. E. Weller, and D. L. Correll. 2003. Sources of nutrient inputs to the Patuxent River estuary. Estuaries 26:226-243.

Kellogg, D. Q., A. J. Gold, P. M. Groffman, M. H. Stolt, and K. Addy. 2008. Riparian ground-water flow patterns using flownet analysis: evapotranspiration-induced upwelling and implications for $\mathrm{N}$ removal. Journal of the American Water Resources Association 44:1024-1034.

Kemp, W. M., et al. 2005. Eutrophication of Chesapeake Bay: historical trends and ecological interactions. Marine Ecology Progress Series 303:1-29.

King, R. S., M. E. Baker, D. F. Whigham, D. E. Weller, T. E. Jordan, P. F. Kazyak, and M. K. Hurd. 2005. Spatial considerations for linking watershed land cover to ecological indicators in streams. Ecological Applications 51:137-152.

Langland, M. J., P. L. Lietman, and S. Hoffman. 1995. Synthesis of nutrient and sediment data for watersheds within the Chesapeake drainage basin. U.S. Geological Survey Water Resources Investigations Report 95-4233. Lemoyne, Pennsylvania, USA.

Linker, L. C., G. W. Shenk, R. L. Dennis, and J. S. Sweeney. 2000. Cross-media models of the Chesapeake Bay watershed and airshed. Water Quality and Ecosystems Modeling 1:91:122.

Liu, Z.-J., D. E. Weller, D. L. Correll, and T. E. Jordan. 2000. Effects of land cover and geology on stream chemistry in watersheds of Chesapeake Bay. Journal of the American Water Resources Association 36:1349-1365.

Lowrance, R. R., et al. 1997. Water quality functions of riparian forest buffers in Chesapeake Bay watersheds. Environmental Management 21:687-712.

Lowrance, R. R., R. Todd, J. Fail, O. Hendrickson, R. Leonard, and L. Asmussen. 1984. Riparian forests and nutrient filters in agricultural watersheds. BioScience 34:374377.

Maxted, J. T., M. W. Diebel, and J. Vander Zanden. 2009. Landscape planning for agricultural non-point source pollution reduction II: balancing watershed size, number of watersheds, and implementation effort. Environmental Management 43:60-68.

Mayer, P. M., S. K. Reynolds, M. D. McCutchen, and T. J. Canfield. 2007. Meta-analysis of nitrogen removal in riparian buffers. Journal of Environmental Quality 36:1172-1180.

McClain, M. E., E. W. Boyer, C. L. Dent, S. E. Gergel, N. B. Grimm, P. M. Groffman, S. C. Hart, J. W. Harvey, C. A. Johnston, E. Mayorga, W. H. McDowell, and G. Pinay. 2003. Biogeochemical hot spots and hot moments at the interface of terrestrial and aquatic ecosystems. Ecosystems 6:301-312.

McGlynn, B. L., and J. Seibert. 2003. Distributed assessment of contributing area and riparian buffering along stream networks. Water Resources Research 39:WR001521.

Mulholland, P. J., A. M. Helton, G. C. Poole, R. O. Hall, S. K. Hamilton, B. J. Peterson, J. L. Tank, L. R. Ashkenas, L. W. Cooper, and S. L. Johnson. 2008. Stream denitrification across biomes and its response to anthropogenic nitrate loading. Nature 452:202-205.

Murphy, P. N. C., J. Ogilvie, and P. Arp. 2009. Topographic modelling of soil moisture conditions: a comparison and verification of two models. European Journal of Soil Science 60:94-109.

National Research Council. 2004. Adaptive management for water resources project planning. National Academy Press, Washington, D.C., USA.

Neter, J., W. Wasserman, and M. H. Kutner. 1990. Applied linear statistical models. Richard D. Irwin, Inc., Burr Ridge, Illinois, USA.

Newbold, J. D., S. Herbert, B. W. Sweeney, P. Kiry, and S. J. Alberts. 2010. Water quality functions of a 15-year-old riparian forest buffer system. Journal of the American Water Resources Association 46:299-310.

Norton, M. M., and T. R. Fisher. 2000. The effects of forest on stream water quality in two coastal plain watersheds of the Chesapeake Bay. Ecological Engineering 14:337-361.

O'Brien, R. M. 2007. A caution regarding rules of thumb for variance inflation factors. Quality and Quantity 41:673-690.

O'Callaghan, J. F., and D. M. Mark. 1984. The extraction of drainage networks from digital elevation data. Computer Vision, Graphics, and Image Processing 28:323-344.

Omernik, J. M., A. R. Abernathy, and L. M. Male. 1981. Stream nutrient levels and proximity of agricultural and forest land to streams: some relationships. Journal of Soil and Water Conservation 36:227-231. 
O'Neill, M. P., J. C. Schmidt, J. P. Dobrowolski, C. P. Hawkins, and C. M. U. Neale. 1997. Identifying sites for riparian wetland restoration: application of a model to the upper Arkansas River basin. Restoration Ecology 5:85-102.

O’Neill, R. V., C. T. Hunsaker, S. P. Timmins, B. L. Jackson, K. B. Jones, K. H. Riitters, and J. D. Wickham. 1996. Scale problems in reporting landscape pattern at the regional scale. Landscape Ecology 11:169-180.

Osborne, L. L., and D. A. Kovacic. 1993. Riparian vegetated buffer strips in water-quality restoration and stream management. Freshwater Biology 29:243-258.

Osborne, L. L., and M. J. Wiley. 1988. Empirical relationships between land use/cover and stream water quality in an agricultural watershed. Journal of Environmental Management 26:9-27.

Peterjohn, W. T., and D. L. Correll. 1984. Nutrient dynamics in an agricultural watershed: observations on the role of a riparian forest. Ecology 65:1466-1475.

Phillips, J. D. 1989. An evaluation of the factors determining the effectiveness of water quality buffer zones. Journal of Hydrology 107:133-145.

Preston, S. D., and J. W. Brakebill. 1999. Application of spatially referenced regression modeling for the evaluation of total nitrogen loading in the Chesapeake Bay watershed. Water Resources Investigations Report 99-4054. U.S. Geological Survey, Baltimore, Maryland, USA.

R Development Core Team. 2008. R: a language and environment for statistical computing. R Foundation for Statistical Computing, Vienna, Austria.

Rabalais, N. N., R. E. Turner, and W. J. Wiseman. 2001. Hypoxia in the Gulf of Mexico. Journal of Environmental Quality 30:320-329.

Rosenblatt, A. E., A. J. Gold, M. H. Stolt, P. M. Groffman, and D. Q. Kellogg. 2001. Identifying riparian sinks for watershed nitrate using soil surveys. Journal of Environmental Quality 30:1596-1604.

Sabater, S., A. Butturini, J. Clement, T. Burt, D. Dowrick, M. Hefting, V. Matre, G. Pinay, C. Postolache, M. Rzepecki, and F. Sabater. 2003. Nitrogen removal by riparian buffers along a European climatic gradient: patterns and factors of variation. Ecosystems 6:20-30.

SAS Institute. 2004. SAS 9.1.3. SAS Institute, Cary, North Carolina, USA.

Seibert, J., and B. L. McGlynn. 2007. A new triangular multiple flow direction algorithm for computing upslope areas from gridded digital elevation models. Water Resources Research 43:W04501.

Simley, J. D., and W. J. Carswell, Jr. 2009. The national maphydrography: fact sheet 2009-3054. U.S. Geological Survey, Washington, D.C., USA.

Smith, A. C., N. Koper, C. M. Francis, and L. Fahrig. 2009. Confronting collinearity: comparing methods for disentangling the effects of habitat loss and fragmentation. Landscape Ecology 24:1271-1285.

Smith, R. A., G. E. Schwarz, and R. B. Alexander. 1997. Regional interpretation of water-quality monitoring data. Water Resources Research 33:2781-2798.

Speiran, G. K. 2010. Effects of groundwater-flow paths on nitrate concentrations across two riparian forest corridors.
Journal of the American Water Resources Association 46:246-260.

Tarboton, D. G., and M. E. Baker. 2008. Toward an algebra for terrain-based flow analysis. Page 167-194 in N. Mount, G. Harvey, G. Priesthall, and P. Apin, editors. Representing, modeling, and visualizing the natural environment. Innovations in GIS series. CRC Press-Taylor and Francis, London, UK.

Tomer, M. D., M. G. Dosskey, M. R. Burkart, D. E. James, M. J. Helmers, and D. E. Eisenhauer. 2009. Methods to prioritize placement of riparian buffers for improved water quality. Agroforestry Systems 75:17-25.

Tomer, M., D. E. James, and T. M. Isenhart. 2003. Optimizing the placement of riparian practices in watershed using terrain analysis. Journal of Soil and Water Conservation 58:198 206.

Turner, R. E., and N. N. Rabalais. 1991. Changes in Mississippi River water quality this century. BioScience 41:140-47.

U.S. Environmental Protection Agency. 2000. Multi-Resolution Land Characteristics Consortium (MRLC) database. U.S. Environmental Protection Agency, Washington, D.C., USA. 〈http://www.epa.gov/mrlcpage

U.S. Environmental Protection Agency. 2006. Protecting the forests of the Chesapeake watershed. Chesapeake Executive Council Directive No. 06-1, U.S. Environmental Protection Agency, Washington, D.C., USA. 〈http://www.chesapeakebay. net/content/publications/cbp_12604.pdf $\rangle$

U.S. Environmental Protection Agency. 2009. Health and restoration assessment: riparian forest buffers planted. U.S. Environmental Protection Agency, Washington, D.C., USA. 〈http://www.chesapeakebay.net/status_forestbuffers.aspx? menu\%20item $=19723\rangle$

Vidon, P., C. Allan, D. Burns, T. P. Duval, N. Gurwick, S. Inamdar, R. Lowrance, J. Okay, D. Scott, and S. Sebestyen. 2010. Hot spots and hot moments in riparian zones: potential for improved water quality management. Journal of the American Water Resources Association 46:278-298.

Vidon, P., C. Allan, and R. Lowrance. 2008. Generalizing riparian zone function at the landscape scale. Water Resources Impact 10:12-14.

Vidon, P. G. F., and A. R. Hill. 2004. Landscape controls on nitrate removal in stream riparian zones. Water Resources Research 40:W03201.

Vogelmann, J. E., T. Sohl, and S. M. Howard. 1998a. Regional characterization of land cover using multiple sources of data. Photogrammetric Engineering and Remote Sensing 64:4567.

Vogelmann, J. E., T. Sohl, S. M. Howard, and D. M. Shaw. 1998b. Regional land cover characterization using Landsat Thematic Mapper data and ancillary data sources. Environmental Monitoring and Assessment 51:415-428.

Weller, D. E., T. E. Jordan, and D. L. Correll. 1998. Heuristic models for material discharge from landscapes with riparian buffers. Ecological Applications 8:1156-1169.

Weller, D. E., T. E. Jordan, D. L. Correll, and Z. J. Liu. 2003. Effect of land-use change on nutrient discharges from the Patuxent River watershed. Estuaries and Coasts 26:244-266.

\section{APPENDIX}

